612. 466.64

インヂカン定量に関する実験的研究

第 二 編

尿、インヂカン定量に関する実験的研究

岡山大学医学部平木内科室（主任：雨木 潔授）

副手進東勉

〔昭和 31 年 3 月 15 日受稿〕

内容目次

第一章 緒 言

第二章 基礎実験並びそ成績

第一項 Tiの固有色を対象とする漂度測 定方法

第二項 Tiの対発烟塩酸呈色反応を対象 とする濃度測定方法

\section{第三章 実験方法の概要}

第一項 被 検 尿

第二項 定 量 法

A 定量術式

(1) 第 1 定量術式

(2) 第 2 定量術式

(3) 第 3 定量術式

B 脱水「ク」浸中の Ti の定量原理

(1) 第 1 定量原理

(2) 第 2 定量原理

C 測定方法

(1) Stufenphotometrie

(2) 比色測定法

D 定量值算出方法

第三項 $\mathrm{V}$ 量

第四項「ク」浸層の容量

第五項 洗液分離量

第四章 実験並びに契験成績

実験 1 定量值に及ほする成時間の影響 並び飞術式, 原理, 測定方法に よる定量値誤差飞就いて

実験方法

実験成績

実験 2 遠藤氏規準液の評価に就いて
実験方法

実験成績。

実験 3 各種酸化剂の評価に就いて

奏験方法

実験成績

㫪験 4 被検尿中醋酸並びに三㜔化醋酸 濃度の定量值に及ほす影響に就 いて

A 原理 (1) Kよる $\mathrm{Ti}$ 值此較实験

実験方法

実験成績

B 原理 (1) 及び原理 (2) Kよる $\mathrm{Ti}$ 值 比較笑験

笑験方法

奏験成績

尖験 5 三塩化醋酸含有尿に於ける定量 值とクロ、フォルム浸水洗の影

響飞就いて

実験方法

実験成績

実験 6 尿清澄刘使用による定量值低下 飞就いて

実験方法

奏験成績

契験 7 インチカン微量定量法の創案並 びそ正常尿インチカン値に就い $\tau$

1 私が創案したインヂカン微量定量 法

2 正常尿インチカン值 
第五章 総括並びに考按．

1 定量值に及ぼす反応時間の影響及 び三椣'这量術式の部洒に就いて

2 迹藤氏淠準液の㲅価に就いて

3 各種酸化郕の詊価飞就いて

4 醋酸並びに三塩化酛酸含有尿に於 ける定量值変動に就いて

5 尿清澄剂による定量值低下に就い

\section{第一章 緒 言}

Jaffé1)による最初の尿インヂカン定量 法の発見以来, Salkowski ${ }^{2)}$, Obermayer ${ }^{3)}$, Wang $^{4) 5)}$, Bouma $^{6)}$, Ellinger ${ }^{7)}$, Imabuchi ${ }^{8)}$, Strauss $^{9)}$, Maillard ${ }^{(0)}$, Oerum ${ }^{11)}$, AutenrietFunk ${ }^{12)}$, Stanford ${ }^{13)}$, Fischer-Huppmann ${ }^{14)}$, Jolles ${ }^{15)}$, Heilmeyer ${ }^{16)}, \quad B a r^{17)}$, Eick $^{18)}$, Broeckmeyer 19)，竹内 20)，遠藤 21)，石神 22), 上田 ${ }^{23)}$ ，公文 ${ }^{24) 25), ~ S h a r l i t ~}{ }^{26)}$ ) Zacherl ${ }^{27)}$, Rose-Exton ${ }^{28)}$, Böhm-Grüner ${ }^{29)}$, Schlierbach ${ }^{30)}$, Eucker ${ }^{31) ， B o ̈ h m}{ }^{32}$ 等飞より, 各種の定量原 $\tau$

6) 原理 (1) 及び原理 (2) 飞於ける定量 値間の誤差に就いて

7 正常尿インチカン值より見たる各 秏インヂカン定量法の評価化就い $\tau$

第六章 結 論

文献

理，定量術式及び測定方法飞基いて実験的正 確度に於いては満足するに足る多数の尿イン テカン定量法が創案されている. 然し乍ら此 等の定量法中，従来最も適用されたる代表的 定量法によつて測定し報告された正常尿イン チカン値に関する諸家業績を集録するに，第 1 表の如く其の成績には実に甚だしい相違が ある事が指摘される。各種尿インチカン定量 法の矢験的正確度と実測值との間に見られる 此の著しい矛盾の諸原因を究明し以つて正確 なる尿インチカンの正常值を決定する事は1 ンチカンの生化学的並びに臨床的意義の真相 第 1 表 諸家の測定せる正常尿インヂがン值

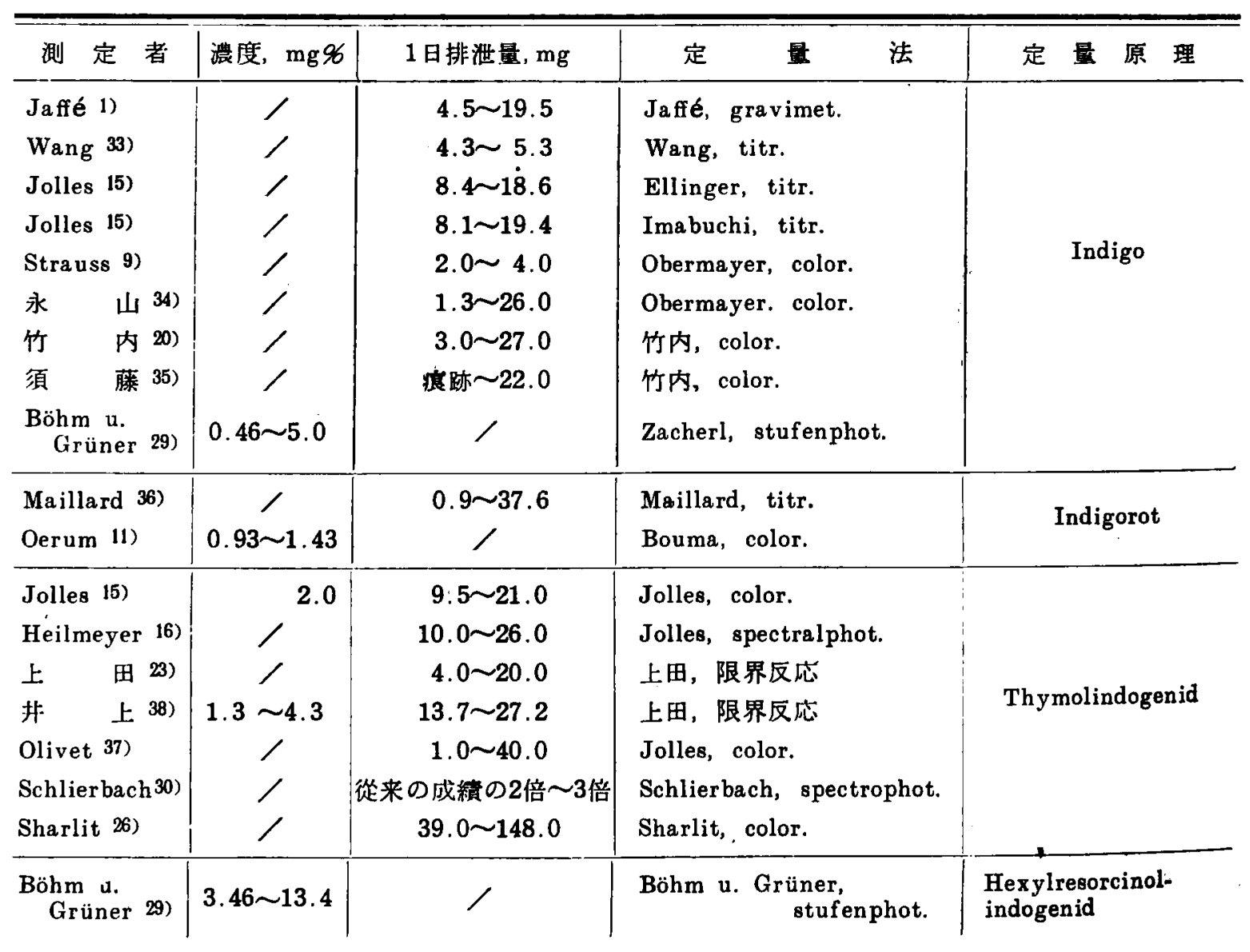


を把握する上飞最る重要なる意義を有する点 飞注目せる私は，Jolles's 反応 ${ }^{39) 15)}$ 及び Jolles・ 竹内・反応40)の呈色本態を明らかにする事に 成功したると端を発し，此の両反応を中心に， 尿インヂカン定量史上, 常飞論争の焦点とな つた定量值の增强又は低下の諸原因に関する 諸家業績を系統的飞究明し，以つて尿インF カンの絶対量を正確に定量し得る微量定量法 を創案すへく企図したのであるが，略々其の 目的を達し得たるを以つて成績の大要を報告 せんとす。

\section{第二章 基整実殹並びに成縝}

クロ、フォルム溶液（以下「ク」溶液と略 す) に於ける Thymolindogenid ( $\mathrm{Ti}$ と略す) の浱度測定方法化就いて検索し, Stufenphotometrie 及び比色法に上る検量曲線及び定型的 Farbkurve を測定した。前者では Pulfrich's Stufenphotometer を使用して $10 \mathrm{~mm}$ 液層で 透過率（D％）を，後者では Hellig's Keil を使用して製出 $\mathrm{Ti}$ の $5 \mathrm{mg} \%$ 「ク」溶液及び $0.5 \mathrm{mg} \%$ 青藍等価遠藤氏規準液を規準液とし て読み（mm）を測定した。

Ti は私が製出し又は合成した赤色プリス 么晶を使用し，尚拓 Ti の対発烟塩酸呈色反 応を検索するに際しては 1 滴が夫々 $0.005 \mathrm{cc}$ 及び $0.01 \mathrm{cc}$ K相当する毛細管ピペットを作 つて器烟塩酸及び無水アルコールの所要量を 測定した。

第一項 $\mathrm{Ti}$ の固有色を対象とする濃度 測定方法

Ti の「ク」溶液に於ける固有の色調は赤裼 色乃至赤橙色で, 密閉選光して保存する時は 其の色調は 2 ケ月後飞於いても不変であり， 其の定型的 Ftarbkurve は第 1 図の如し.

種々なる既知濃度の Ti「ク」溶液に就いて S47及びS 50を使用して測定した透過率は第 2 表, 收光度曲線恃第 3 図の如く, LambertBeer の法則飞従い Ti の濃穈 C (mg\%) は次 式で算出される.

1 S 47 を使用する場合

$$
\mathrm{C}=\mathrm{E} \times 6.38 \quad \text { (製出 } \mathrm{Ti} \text { ) }
$$

$$
\mathrm{C}=\mathrm{E} \times 6.84 \text { （合成 } \mathrm{Ti} \text { ） }
$$

2 S 50 を使用する場合

$$
\begin{array}{ll}
\mathrm{C}=\mathrm{E} \times 6.78 & \text { (製出 } \mathrm{Ti}) \\
\mathrm{C}=\mathrm{E} \times 7.46 & \text { (合成 } \mathrm{Ti})
\end{array}
$$

種々なる既知濃度の製出 $\mathrm{Ti}$ の「ク」溶液に 就いて測定した比色検量曲線は第 5 図の如し。

第二項 $\mathrm{Ti}$ の対発烟塭酸呈色反忍を 対象とする濃度測定方法

遠藤氏法21) （以下脱水「ク」浸と略す）の呈色条件を $\mathrm{Ti}$ 「ク」溶液飞就いて Stufenphotometrie とより 追試したるル，5mg \%及び $2.5 \mathrm{mg} \%$ Ti「ク」 溶液 2cc をして測定に適する均一透明且つ最 強の紫青色着色状態とするには，発烟塩酸 1 滴 $(0.01 \mathrm{cc})$ 及び源濁除去に要する無水アルコ ールの最小必需量は 20 滴 (0.1cc) を要し. 其の色調は調製後 5 分間以内は不変なるも, 以後徐々飞褪色する事を知つた，更飞人尿に 遠藤氏法を適用して得られる脱水「ク」浸 2cc 飞就いて敍上の呈色条件を検したるに， 発烟塩酸 1 滴 $(0.01 \mathrm{cc})$ 飞対し無水アルコー ル26〜23 滴 $(0.13 \sim 0.14 \mathrm{cc})$ を要し且つ紫色 色調の時間的裉色の事奉を認めた。

然して人尿に適用されるべき呈色条件（発 烟塩酸 1 滴, 無水アルコール28滴)に於ける Ti「ク」溶夜の紫青色色調は，其の色調が最 強を示す呈色条件（発烟塩酸 1 滴, 無水アル コール20滴）飞比し其の色調濃度飞於いて約 $4 \%$ の減少を見るも，極めて鮮明且つ濃厚で 測定に適し其の定型的 Farbkurve は第 2 図 の如し。

種々なる既知濃度の $\mathrm{Ti} 「 ク 」$ 溶液 $2 \mathrm{cc}$ に就 いて，発烟塩酸 1 滴及び無水アルコール28滴 なる呈色条件で，調製後直ちに S 57 及び S 53 を使用して測定した透過率は第 2 表, 吸北度 曲線は第 4 図の如く, Lambert-Beer の法則 飞従い $\mathrm{Ti}$ の濃度 $\mathrm{C}(\mathrm{mg} \%)$ は次式で算出さ れる。

1 S 57 を使用する場合 $\mathrm{C}=\mathrm{E} \times 2.48($ 製出 $\mathrm{Ti})$
$\mathrm{C}=\mathrm{E} \times 2.36($ 合成 $\mathrm{Ti})$

2 心 53 を使用する場合 
第2 表 逶過率測定成 績 (㖇出二㖇出 Ti.

\begin{tabular}{|c|c|c|c|c|c|c|c|c|}
\hline \multirow{4}{*}{$\begin{array}{l}\mathrm{Ti} \text {. 㗳度 } \\
\text { (mg\%) }\end{array}$} & \multicolumn{3}{|c|}{ 透 } & 過 & 辛 & \multicolumn{3}{|c|}{ ( D \%，10 mm 液層) } \\
\hline & \multirow{2}{*}{\multicolumn{2}{|c|}{$\begin{array}{l}\text { 原 } \\
\text { S. } 47\end{array}$}} & \multicolumn{2}{|l|}{ 理 } & \multirow{2}{*}{\multicolumn{2}{|c|}{ 原 }} & \multicolumn{2}{|l|}{2} \\
\hline & & & \multicolumn{2}{|c|}{ S. 50} & S. 57 & & \multicolumn{2}{|c|}{ S. 53} \\
\hline & 出合 & 合 & 慗 出 & 合 成 & 製 出 & 成 & 製出 & 合 成 \\
\hline 5.0 & 16.8 & 19.4 & 19.0 & 21.5 & 1.1 & 0.9 & 1.6 & 1.5 \\
\hline 4.5 & 20.5 & 22.5 & 22.0 & 25.0 & 1.7 & 1.3 & 2.2 & 2.1 \\
\hline 4.0 & 24.5 & 26.5 & 26.2 & 29.5 & 2.6 & 2.2 & 3.5 & 3.4 \\
\hline 3.5 & 29.0 & 31.0 & 30.5 & 34.0 & 4.2 & 3.6 & 5.8 & 5.5 \\
\hline 3.0 & 34.8 & 36.0 & 36.0 & 40.0 & 6.0 & 5.5 & 8.2 & 7.8 \\
\hline 2.5 & 40.0 & 43.0 & 42.0 & 46.0 & 10.0 & 8.8 & 12.0 & 11.0 \\
\hline 2.25 & 44.0 & 45.5 & 46.5 & 48.5 & 12.3 & 10.6 & 14.5 & 13.5 \\
\hline 2.0 & 48.0 & 50.5 & 50.2 & 53.5 & 16.0 & 13.8 & 18.0 & 17.5 \\
\hline 1.75 & 53.5 & 55.0 & 55.0 & 57.3 & 19.3 & 18.0 & 21.8 & 20.4 \\
\hline 1.5 & 58.0 & 60.4 & 60.0 & 63.0 & 24.5 & 23.0 & 27.0 & 26.5 \\
\hline 1.25 & 63.2 & 66.0 & 65.0 & 68.5 & 30.0 & 29.0 & 32.0 & 31.0 \\
\hline 1.0 & 69.5 & 70.5 & 71.0 & 73.0 & 39.0 & 37.6 & 42.0 & 41.2 \\
\hline 0.75 & 76.5 & 78.0 & 77.5 & 80.0 & 49.5 & 48.0 & 52.5 & 51.5 \\
\hline 0.5 & 83.0 & 85.0 & 84.5 & 86.0 & 61.5 & 60.5 & 63.5 & 63.0 \\
\hline 0.25 & 91.0 & 93.0 & 92.5 & 93.0 & 79.0 & 80.0 & 80.5 & 81.0 \\
\hline 0.125 & 95.0 & 96.0 & 96.0 & 96.5 & 88.5 & 90.0 & 89.0 & 91.0 \\
\hline 0.05 & $98.0 \sim 100$ & 98.0 & 98.0 & 98.0 & 96.0 & 97.0 & 97.0 & 96.0 \\
\hline 0.025 & $98.0 \sim 100$ & 100 & $98.0 \sim 100$ & $98.0 \sim 100$ & 98.0 & 98.0 & 98.0 & $98.0^{\circ}$ \\
\hline 対 & $98.0 \sim 100$ & 100 & $98.0 \sim 100$ & $99.0 \sim 100$ & $98.0 \sim 100$ & $99.0 \sim 100$ & 100 & 100 \\
\hline
\end{tabular}

第 1 図 Ti.「ク」溶液の定型的 Farbkurve （原理 (1))

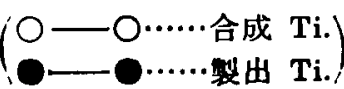

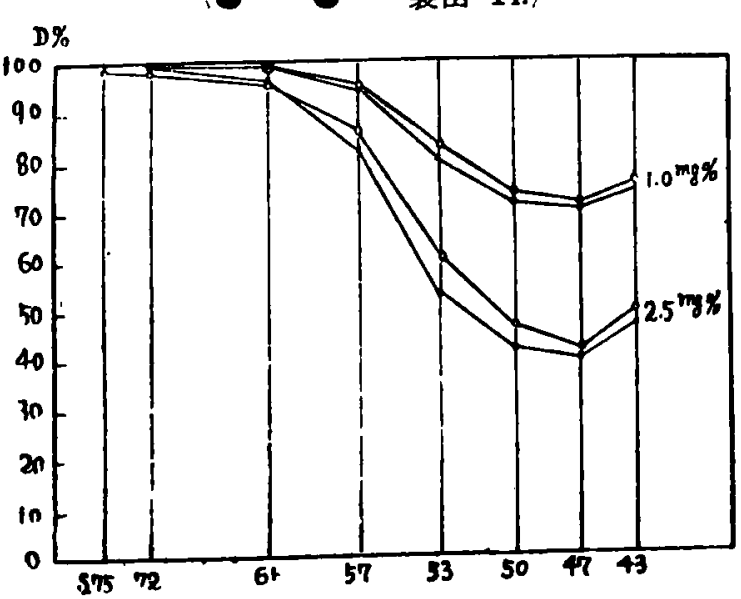

第 3 図 吸光度曲線（原理 (1)）

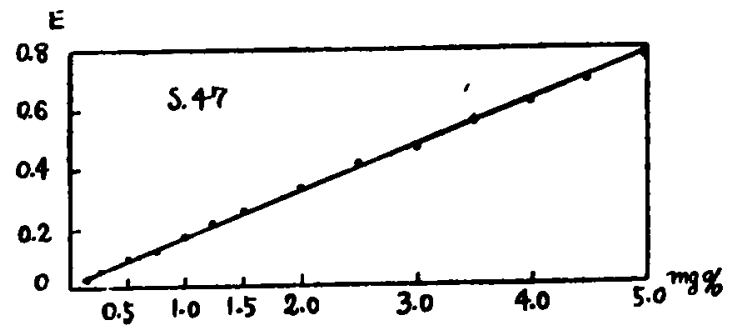

第 2 図 Ti.「ク」溶液の定型的 Farbkurve (原理 (2))

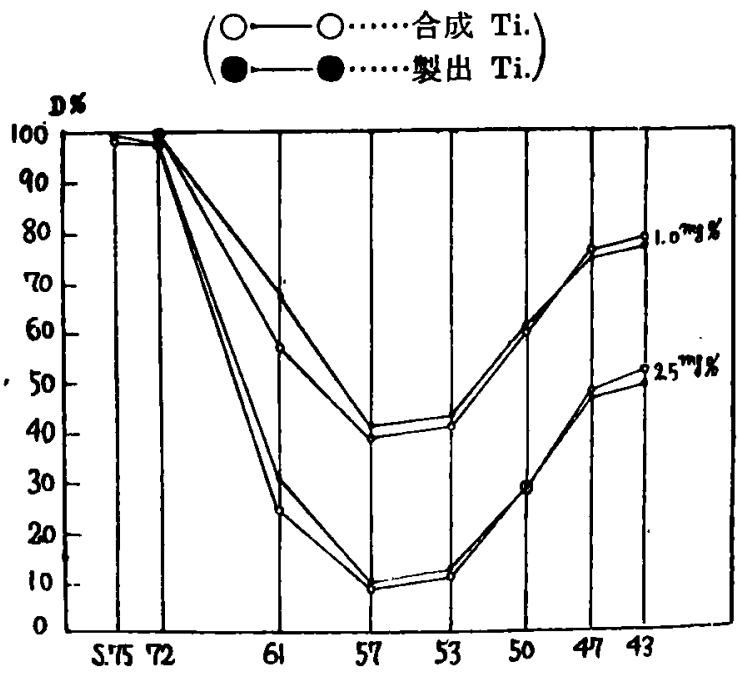

第 4 図 吸光度妕線（原理 (21)

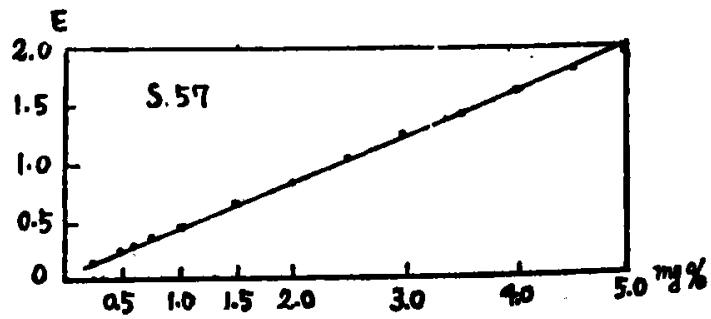


第 5 図 此色検量曲線（規準液 $=5 \mathrm{mg} 96$

Ti.「ク」溶液）

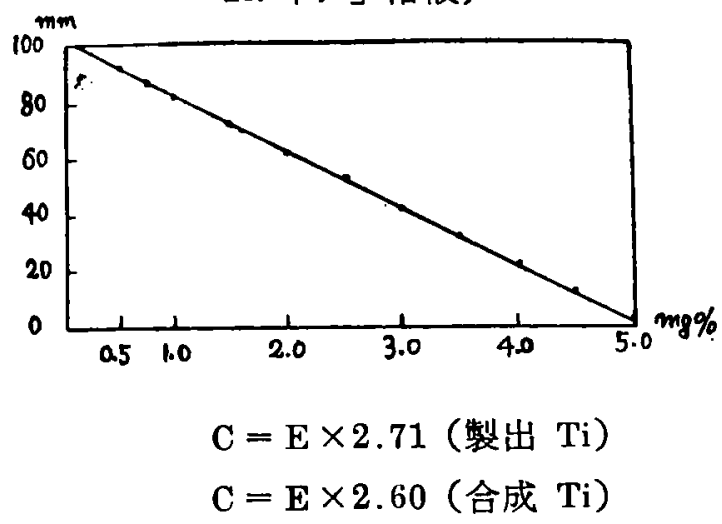

種々なる既知濃度の遠藤氏規準液に就いて 測定した比色検量曲線は第 6 図の如し.

\section{第三章 実臨方法の概要}

\section{第一項 被検尿}

インドール負荷家鬼 24 時間尿及び健康人尿
第 6 図此色検量曲線（規準液 $=0.5 \mathrm{mg} \%$ 青監等価遠櫒氏液）

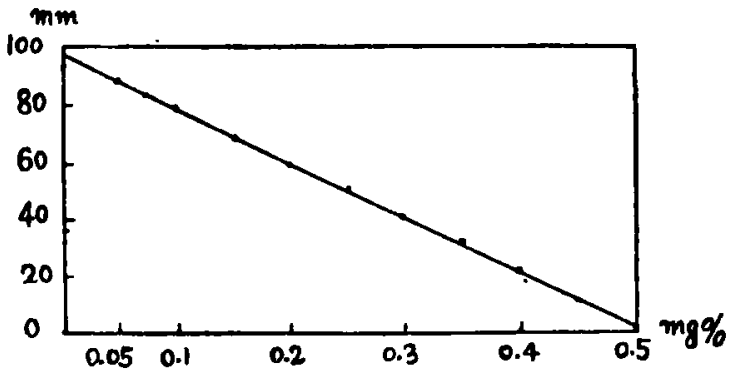

を使用した．前者ではインドール 20〜40 mg を純胡麻油 $4 \mathrm{cc}$ 飞溶解して成熟家鬼背部皮下 に注射乙其の 24 洔間尿を飼料及び䔬塊の混入 せざる様に注意して蓄尿した，実䮖に使用し た被検尿は第 3 表の如し.

\section{第二項 定量法}

\section{A 定量術式}

Jolles 氏法 ${ }^{15)}$ 及び嵒藤氏法21) の原理及び 第分表被
検尿

\begin{tabular}{|c|c|c|c|c|c|c|c|c|c|}
\hline \multirow{2}{*}{$\begin{array}{l}\text { 実験 } \\
\text { 番号 }\end{array}$} & \multicolumn{2}{|r|}{ 被 } & 检 & \multicolumn{3}{|c|}{ 尿 } & \multicolumn{2}{|c|}{ 家冤 } & \multirow{2}{*}{$\mid \begin{array}{c}\text { A } \\
\text { 角荷 } \\
\mathrm{mg}\end{array}$} \\
\hline & 番号 & 類 & 総星 $c c$ & 色 調 & 性 & 比重 & 性 & 体重 $\mathrm{kg}$ & \\
\hline 1 & No. 1 & インドール負荷家芯24侍間尿 & 309 & 淡黄裮 & A & 1.017 & $q$ & 2.36 & 40 \\
\hline 3 & No. 2 & 趾 康人 早朝 尿 & 224 & $"$ & $\mathbf{s}$ & 1.024 & / & 1 & I \\
\hline $4 \mathrm{~A}$ & No. 3 & イントーール負荷家鬼24時間尿 & 225 & $"$ & $\mathbf{A}$ & 1.017 & 우 & 2.65 & 40 \\
\hline $4 \mathrm{~B}$ & No. 4 & 健 康 $人 24$ 時 間 尿 & 2230 & 淡 黄 & $\mathrm{s}$ & 1.014 & I & 1 & I \\
\hline $\mathbf{5}$ & No. 5 & インドール目荷家鬼24恃間尿 & 276 & 黄 楬 & $\mathbf{A}$ & 1.015 & $\hat{o}$ & 2.40 & 40 \\
\hline \multirow{2}{*}{6} & No. 6 & 硉 康人 24 時 間 尿 & 1520 & 淡 黄 & $\mathrm{s}$ & 1.017 & l & ノ & $/$ \\
\hline & No. 7 & 踺 康 人 24 時 間 尿 & 2030 & " & $\mathrm{s}$ & 1.014 & I & I & 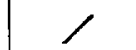 \\
\hline
\end{tabular}

術式を比較検討し，次の三種の定量術式を試 案して，尿インデカンを Ti に誘導した後， 之れを $\mathrm{Ti}$ の固有色（赤裮色）として抽出し た脱水「ク」浸を作つた。

(1) 第 1 定量術式（術式(1)と略す）

迋藤氏法に於ける異常なるクロ、フォルム の注加順序を正規化し且つ反応洔間を 2 時間 飞改め, 次の如く策施した。

㴓尿 $1 \mathrm{cc}$ 試験管飞採り, 醋酸 2 滴, 水 $4 \mathrm{cc}$ を加えて 5 倍稀积となし，5％チモールア ルコール0.5cc，竹内氏試楽 $0.23 \mathrm{c}$ を加光 て軽振瓷し，発烟塩要 5cc を注加して室温 に2時間反忘せしめたる缓、クロ、フォルム
$3 c$ を加えて管口を密栓し，上下に 50 回強 振湦して色素を抽出す。試験管を静置して 「ク」浸を完全に分離せしめ(第 1 回抽出), 母液を吸引除上して他の試験管に移し第 2 回色溸抽出を行う。「ク」浸は水 $5 \mathrm{cc}$ で 2 回水洗したる度, $\mathrm{n} / 50$ 次要硫酸ソータ液 をビウレットから滴下しつつ，1％澱粉液 2 滴を加兄て強振滥し，「ク」浸中の沃度 を完全に中和す次亚硫酸ソー夕液を吸引 除去した後, 更に水 $3 \mathrm{cc}$ で 4 回反婹して 「ク」浸を水洗し，最終回洗液を可及的完 全飞吸引除去したる後，無水硫酸ソータ $2 \mathrm{~g}$ を投じて「ク」浸を脱水す．赤褐色透明な 
勉.

脱水「ク」浸を $10 \mathrm{cc}$ 有栓メスチリンデル に移し，管内に残留する色素は更に少冝の クロ、フォルムを加えて全部之れを抽出し， 全脱水「ク」浸を合して一定量 $(6 \sim 8 \mathrm{cc})$ とす。

（2）第 2 定量術式（術式 (2) と略す). 術式(1)と巽なる点は，クロ、フォルムの 注加順序にして遠藤氏法飞準拠せり。即方 クロ、フォルムは予め発烟塩酸注加前に入 れる事とした。

（3）第 3 定量術式（術式(3)と略す).

術式(1)と異なる点な酸化剂として, Jolles 氏法に準拠して次の如く笑施した。

滤尿 $1 \mathrm{cc}$ 醋酸 2 滴，水 $4 \mathrm{cc}$ を加えて 5 倍稀釈となし，5\%チモールアルコール $0.5 \mathrm{cc}$ を加えて軽振望し， $0.5 \%$ Obermayer's 試蔡 $5 \mathrm{cc}$ を加えて室温に 2 時間反心せしめ たる後, 術式(1)に染じて色素の第 1 回及び 第 2 回抽出を行 5. 母液と完全飞分離せし めた「ク」浸注水 $5 \mathrm{cc} て ゙ 2$ 回水洗したる後, 更飞水: 3cc 4 回水洗し, 以後術式(1)と同 様化して赤褐色透明なる脱水「ク」浸を合 して一定量（6〜8cc）とした。

B 脱水「ク」浸中の $\mathrm{Ti}$ の定量原理 基礎资駼成績基いて次の二つの定量原理 を同時に採用した。

（1）第 1 定量原理（原理（1）と略す）

Tiの固有色（赫褐色）を対象とする方法 であり，脱水「ク」浸の赤褐色出調を其の 倎， $\mathrm{Ti}$ の固有色と見なして定量した.

（2）第 2 定量原理（原理 (2) 之略す）.

$\mathrm{Ti}$ の対発烟塭酸呈色反念 (紫青色) を対 象とする方法で，脱水「ク」浸 $2 \mathrm{cc}$ 飞発烟 壏酸 1 滴 $(0.01 \mathrm{cc})$ 及び無水アルコール26 〜28滴（0.13〜0.14 cc）を加兑て混液をし て均一唀明且つ最強の紫青色となした直後 の色調を対象として定量した。

C 測定方法

(1) Stufenphotometrie

Pulfrich's Stufenphotometer を使用し， $10 \mathrm{~mm}$ 液層で原理 (1)飞はS47を，原理(2)飞 はS57を適用して逶過得（D％）を测它す
ると共に必要に吢じて Farbkurve を測定 した.

（2）比色測定法

Hellig's Keil を使用し原理 (1) とは製出 Ti の 5mg 96 「ク」溶液を，原理(2)《は 0.5 $\mathrm{mg} \%$ 青篮等価遠藤氏規準液を使用して読

み（mm）を測定した。

D 定量值算出方法

篹験成績飞於ける尿インデカン值（mg \%) は凡て $\mathrm{Ti}$ 值（製出 $\mathrm{Ti} \mathrm{mg} \%$ ）として算出し た.

透過率（D％）及び読み（mm）からする Ti値は何れ子基礎実験成績飞於ける検量曲線 を利用した，

(1) $\mathrm{C}_{8} \mathrm{H}_{6} \mathrm{NO}_{4} \mathrm{SK}+\mathrm{H}_{2} \mathrm{O} \rightarrow \mathrm{C}_{8} \mathrm{H}_{7} \mathrm{NO}+\mathrm{KHSO}_{4}$ Indikan Indoxyl

(2) $\mathrm{C}_{8} \mathrm{H}_{7} \mathrm{NO}+\mathrm{C}_{10} \mathrm{H}_{14} \mathrm{O}+\mathrm{O}_{2} \rightarrow \mathrm{C}_{18} \mathrm{H}_{17} \mathrm{NO}_{2}+2 \mathrm{H}_{2} \mathrm{O}$ Indoxyl Thymol Thymolindogenid

(3) $\mathrm{C}_{8} \mathrm{H}_{7} \mathrm{NO}+\mathrm{C}_{8} \mathrm{H}_{7} \mathrm{NO}+\mathrm{O}_{2} \rightarrow \mathrm{C}_{16} \mathrm{H}_{10} \mathrm{~N}_{2} \mathrm{O}_{2}+2 \mathrm{H}_{2} \mathrm{O}$ Indoxyl Indoxyl Indigo

以上の反忍式から下式が成立する。

(1) インチカン值 $=\mathrm{Ti}$ 値 $\times 0.9$

(2) $\mathrm{Ti}$ 値 $=$ 青監值 $\times 2.13$

\section{第三項 V量}

$\mathrm{V}$ 量とは，理論上赤褐色であるべき脱水 「ク」浸中心混色として出現する紫色色調の 浱嬑の意味であり，便宜上私は之を $\mathrm{Ti}$ 濃度 （mg芯）として表現した，即ちマ量の測定は 脱水「ク」浸の原理(1)飞S 57 を適用して透過 率を測定し，此の透過率に相当する $\mathrm{Ti}$ 濃度 を原理(2)，S 57亿適用されるへき検量曲線か ら算出した。

第四項「ク」浸層の容量

第 1 回色素抽出時, 母液と完全飞分離沈降 せしめたる「ク」浸層の谷量にして，其の測 定は予め「ク」浸層の高さを測定して置き, 実 験終了後, 内容を清洗乾燥せる同一試験管飞, 測定したる「ク」浸層の高さに相当する水量 をビウレットから注下して測定した。

第五項 洗液分離量

「ク」浸つ第 1 回及び第 2 回水洗液を可及 的完全に吸引して其 つ容量を測定した。 


\section{第四草 実検並びに実䀦成綪}

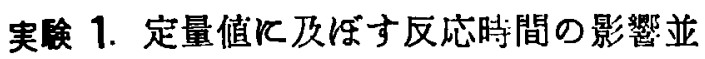
びそ術式，原理，測定方法による 定量值誤差飞就いて

\section{実 酫 方 法}

被検尿 No. 1 を使用し，術式(1)，術式 (2), 術式(3)《於ける反応時間 2 時間を夫々次の如 〈短縮した．即ち第 1 回色素抽出を発娾塩酸 注加後，直ちに (直後) 又は 5 分，10分，:0 分，60分及び 120 分後飞実施した。実騃例は 各反応時間に就き 2 倿宛とし, 其の半数例飞 於いて第 2 回色素抽出を行い，脱水「ク」浸
の総量は 7cr（第 1 回抖出時）贝び4cc（第 2 回抽出時）とし，原理(1)及び原理(2)飞基いて Stufenphotometrie 队び比色法によりインヂ カン値を測定すると共に，原理(1)及び原理(2) に於ける Farbkurve を測定した。

\section{実 験 成 繦}

成續は第 4 表，第 7 図，第 8 図，第 9 図飞 示す如し。

(1) 定量值と反态時間の関係

第 4 表注示す如く, 術式, 原理, 測定方法 を同じくする Ti 值は測定不適なりし比色值 （( ）内に示す）を除き，2時間値が最高值 を，直後健が最低值を示した。 Stufenphoto-

第 4 表 種々なる反応時間，術式，原理，測定方江飞よる Ti. 值 $\mathrm{mg}$ \% 測定成績

\begin{tabular}{|c|c|c|c|c|c|c|c|c|c|}
\hline \multirow{3}{*}{$\begin{array}{l}\text { 定 } \\
\text { 量 } \\
\text { 術 } \\
\text { 式 }\end{array}$} & \multirow{3}{*}{$\begin{array}{l}\text { 反 } \\
\text { 応 } \\
\text { 時分 } \\
\text { 間銤 }\end{array}$} & \multirow{3}{*}{$\begin{array}{l}\text { 試 } \\
\text { 験 } \\
\text { 番 } \\
\text { 号 }\end{array}$} & \multicolumn{3}{|r|}{ 二 } & \multirow{2}{*}{\multicolumn{2}{|c|}{ 抽 }} & \multicolumn{2}{|c|}{ 第三回抽出 } \\
\hline & & & \multirow[b]{2}{*}{$\mid \begin{array}{c}\text { 䛤水厂ク」浸 } \\
\text { 色 調 }\end{array}$} & \multicolumn{2}{|c|}{ Stufenphot. } & & & \\
\hline & & & & $\begin{array}{l}\text { 原理 (1) } \\
(\mathrm{S} .47)\end{array}$ & $\begin{array}{c}\text { (2) } \\
\text { (S. 57) }\end{array}$ & 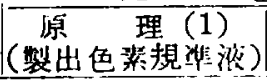 & 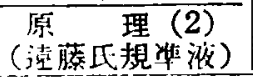 & $\begin{array}{l}\text { 原理 (1) } \\
\text { (S. 47) }\end{array}$ & $\begin{array}{l}\text { 原理 (2) } \\
\text { (S.57) }\end{array}$ \\
\hline \multirow{12}{*}{1} & \multirow{2}{*}{ 直後 } & No. 1 & 赤褐柴 & 10.74 & 5.99 & 比色不能 & 1.72 & 0.70 & 0.38 \\
\hline & & 2 & $"$ & 11.11 & 5.99 & of & 1.73 & $\nearrow$ & \\
\hline & \multirow{2}{*}{5} & 3 & 17 & $10 . \overline{92}$ & 7.32 & "I & 1.88 & 1.05 & $0 . \overline{40}$ \\
\hline & & 4 & "I & 11.29 & 7.31 & " & 2.00 & 1 & \\
\hline & \multirow{2}{*}{10} & 5 & 赤褐喘紫 & 12.97 & 8.70 & $(15.93 \sim 14.38)$ & 2.20 & 0.95 & 0.38 \\
\hline & & 6 & " & 12.95 & 8.44 & $(15.12 \sim 13.58)$ & 2.47 & Z & \\
\hline & \multirow{2}{*}{30} & 7 & 褐 & 13.68 & 9.06 & $16.09 \sim 15.01$ & 2.75 & 0.90 & 0.28 \\
\hline & & 8 & " & 13.48 & 9.41 & $15.30 \sim 14.60$ & 2.63 & 1 & \\
\hline & \multirow{2}{*}{60} & 9 & $" 1$ & 13.65 & 9.41 & $15.63 \sim 14.91$ & 2.71 & 0.75 & 0.25 \\
\hline & & 10 & 11 & 14.09 & 9.67 & $16.03 \sim 15.65$ & 2.76 & & 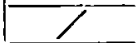 \\
\hline & \multirow{2}{*}{120} & 11 & "I & 14.88 & 9.80 & $16.73 \sim 16.38$ & 2.84 & 0.75 & 0.20 \\
\hline & & 12 & $"$ & 14.09 & 9.98 & $16.38 \sim 16.03$ & 2.80 & I & \\
\hline \multirow{12}{*}{2} & \multirow[b]{2}{*}{ 直後 } & No. 1 & 赤褐些 & $9.80^{-1}$ & 6.34 & 比色不能 & 1.54 & 0.95 & 0.33 \\
\hline & & 2 & 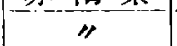 & 8.93 & 5.99 & " & 1.43 & $\nearrow$ & $\bar{Z}$ \\
\hline & \multirow{2}{*}{5} & 3 & $"$ & 9.98 & 7.13 & $" 1$ & 1.96 & 0.95 & 0.30 \\
\hline & & 4 & $"$ & 10.59 & 7.92 & " & 2.27 & 7 & 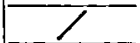 \\
\hline & \multirow{2}{*}{10} & 5 & i & 9.80 & 6.87 & "I & 1.85 & 1.00 & 0.28 \\
\hline & & 6 & " & 8.79 & 5.90 & $"$ & 1.57 & $\nearrow$ & 1 \\
\hline & \multirow{2}{*}{30} & 7 & "I & 9.80 & 6.69 & $" 1$ & 1.77 & 0.85 & 0.20 \\
\hline & & 8 & $"$ & 10.53 & 7.52 & $"$ & 1.98 & 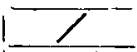 & 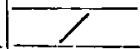 \\
\hline & \multirow{2}{*}{60} & 9 & 浾䘽微紫 & 9.98 & $6 . \overline{96}$ & $(12.60 \sim 10.89)$ & 1.96 & 0.80 & 0.20 \\
\hline & & 10 & i" & 10.56 & 7.22 & $10.69 \sim 10.33$ & 2.03 & 7 & \\
\hline & \multirow{2}{*}{120} & 11 & 狝一褐 & 11.11 & 7.39 & $11.90 \sim 11.55$ & 2.24 & 0.80 & 0.25 \\
\hline & & 12 & " & 13.13 & 8.44 & $14.91 \sim 14.21$ & 2.55 & 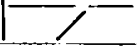 & Y \\
\hline & & No. 1 & 淡 当 & 2.89 & 1.93 & 比色不能 & 0.39 & 0.65 & 0.20 \\
\hline & 䇛後 & 2 & is & $2.80^{-}$ & 2.10 & $"$ & 0.34 & $\gamma$ & 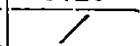 \\
\hline & & 3 & 淡紫谓 & 3.55 & 2.17 & $"$ & 0.39 & 0.50 & 0.18 \\
\hline & 5 & 4 & "I & 3.59 & 2.19 & "I & 0.51 & 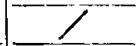 & 1 \\
\hline & & 5 & "I & 3.82 & 2.13 & "I & 0.51 & 0.70 & 0.20 \\
\hline 3 & 10 & 6 & 淡紫褐 & 3.94 & 2.14 & $"$ & 0.59 & 1 & 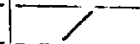 \\
\hline & & 7 & 淡黄褐 & 3.76 & 2.23 & $(4.13 \sim 3.50)$ & 0.59 & 0.50 & 0.15 \\
\hline & 30 & 8 & 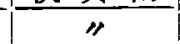 & 3.94 & 2.36 & $(4.76 \sim 3.19)$ & 0.51 & $/$ & 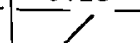 \\
\hline & 60 & 9 & 淡赤褐 & 4.05 & 2.52 & $3.74 \sim 3.60$ & 0.69 & 0.70 & 0.18 \\
\hline & bu & 10 & $"$ & 4.38 & 2.76 & $3.96 \sim 3.64$ & $0 . \overline{79}$ & $\gamma$ & 1 \\
\hline & & 11 & " & 5.58 & 3.69 & $5.87 \sim 5.54$ & 1.02 & 0.75 & 0.20 \\
\hline & 120 & 12 & $"$ & 6.21 & 4.46 & $7.07 \sim 6.93$ & 1.34 & \% & 7 \\
\hline
\end{tabular}


第 7 図定量值上昇曲線

（( ）内の数字は術式の桖颣を示す)

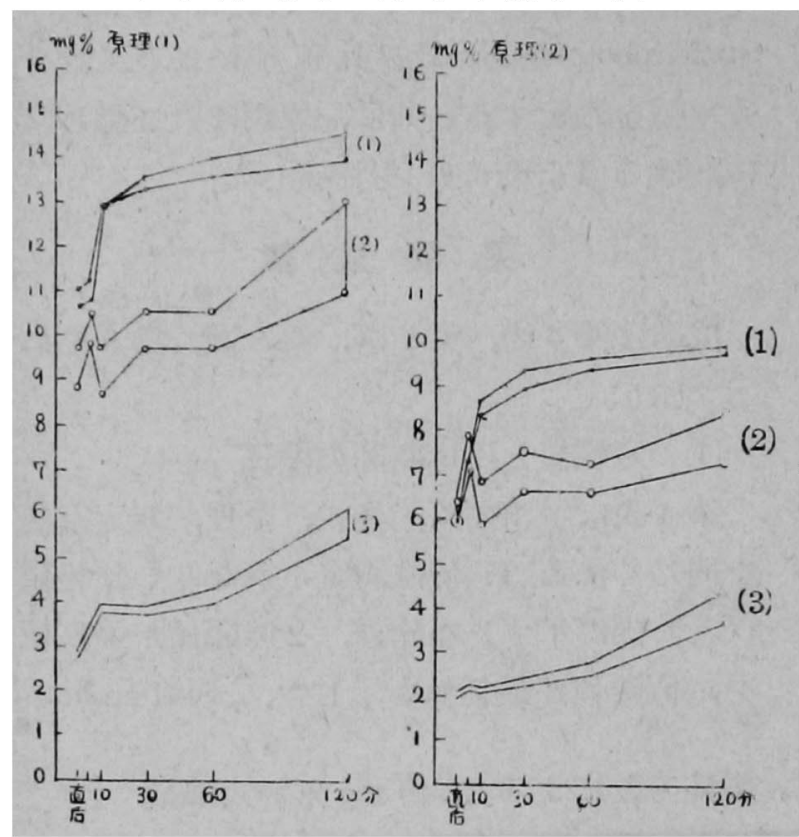

第 5 表 平均 2 時間値百分比（\%6）

\begin{tabular}{|c|c|c|c|c|c|}
\hline \multirow{3}{*}{$\begin{array}{l}\text { 表 } \\
\text { 番 } \\
\text { 号 }\end{array}$} & \multirow{3}{*}{$\begin{array}{l}\text { 繮 } \\
\text { 式 }\end{array}$} & \multicolumn{2}{|c|}{ 第 } & \multicolumn{2}{|l|}{ [回 } \\
\hline & & \multicolumn{2}{|c|}{ Stufenphot. } & 比 & \multirow{2}{*}{ 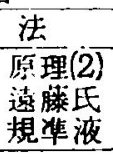 } \\
\hline & & 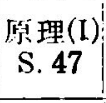 & $\begin{array}{l}\text { 16: 理(2) } \\
\text { S. } 57 \\
\end{array}$ & 製出色素规华液 & \\
\hline \multirow{3}{*}{ No. 1} & - & 100.0 & 100.0 & $100.0 \sim 100.0$ & 100.0 \\
\hline & 2 & 83.6 & 80.1 & $81.0 \sim 79.5$ & 85.1 \\
\hline & 3 & 40.7 & 41.3 & $39.1 \sim 38.5$ & 41.8 \\
\hline \multirow{3}{*}{ No. 2} & 1 & 100.0 & 68.3 & $114.3 \sim 111.9$ & 19.5 \\
\hline & 2 & 100.0 & 65.3 & $110.6 \sim 106.3$ & 19.8 \\
\hline & 3 & 100.0 & 69.2 & $109.7 \sim 105.8$ & 20.0 \\
\hline \multirow{3}{*}{ No. 3} & & .5 & 10 & $167.4 \sim 163.9$ & \\
\hline & 2 & 153.0 & 100.0 & $169.3 \sim 162.6$ & 30.3 \\
\hline & 3 & .0 & 100.0 & $158.6 \sim 152.6$ & 28.9 \\
\hline
\end{tabular}

metrie そよる Ti 值 (Stufo. 值と略す) 飞就 いて見ると術式(1)，術式(2)，術式(3)の 2 時間 值は夫々平均 $14.49 \mathrm{mg} \%, 12.12 \mathrm{mg} \%, 5.90$ $\mathrm{mg} \%$ (以上原理 (1)) 又は $9.89 \mathrm{mg} \%, 7.92 \mathrm{mg} \%$, $4.08 \mathrm{mg} \%$ (以上原理 (2)) であり, 原理, 測 定方法を同じくする 2 時間值は術式(1)に於い て全成績中の最高値を示した.

第 7 図に示す如く，反応洔間の延長飞伴了 Ti值上昇曲線は術式に夫々特有であり，術式 (3) では極めて徐々に，術式 (2) では不規則に， 術式(1)では応時間10分迄は急昇するが30分 以後は極めて徐々に上昇し 2 时間で最高飞達
第 8 図 Farbkurve（原理 (1))

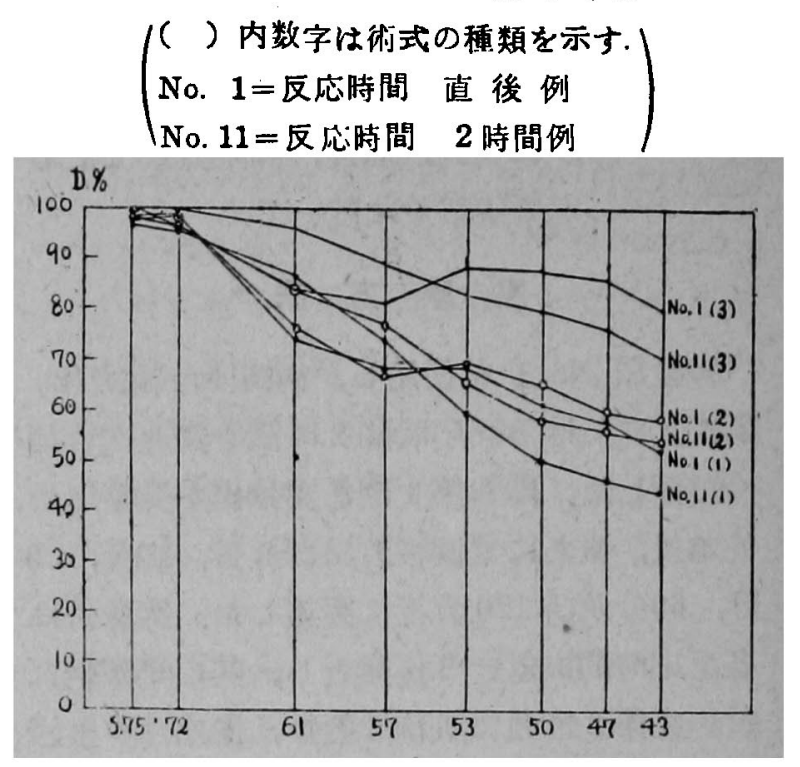

第 9 図 Farbkurve（原理 (2)) $\left(\begin{array}{ll}(） \text { 内数字は術式の種類を示す. } \\ \text { No. } 1 \text { 反瓜時間 } & \text { 直 後 例 } \\ \text { No. 11=反応㭙間 } & 2 \text { 時間例 }\end{array}\right)$

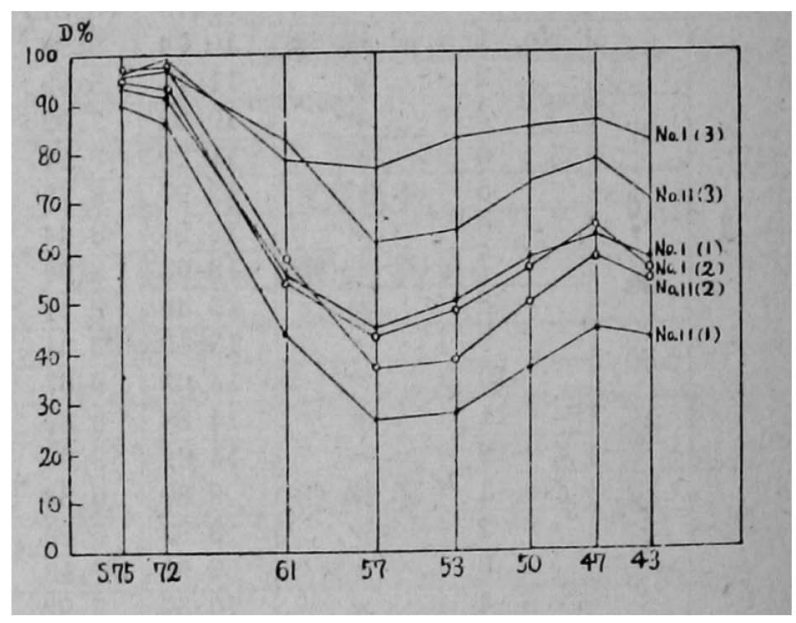

†.

反忍洔間の短縮飞伴 $5 \mathrm{Ti}$ 值低下率を Stufo. 值飞就いて求めると, 最高值を示す 2 時間值 と 1 時間值との䛊差は, 後者に於いて夫々 平均 $-4.3 \sim-3.5 \%$ (術式 (1)), -15.3 $-10.2 \%$ (術式(2))，-35.3〜-28.5\%(術式 (3)）となり，術式(1)仗於いて最小で術式(3)に 於いて最大であり又原理(1)飞よる $\mathrm{Ti}$ 値低下 率が原理(2)飞比して大である。

(2) 定量值と術式の関係

第 4 表飞示す如く，反成時間，原理，測定 方法を夫々同じくする $\mathrm{Ti}$ 値は，術式(1，K於い て最高値を，術式(3)於いて最低值を示す。 
術式(1の 2 時監值飞対する術式 2 及び術式 (3)の 2 時間値の百分比を求めると第 5 表No.1 飞示寸如く夫々平均 79.5 81.5 96（術式 (2)）及び 38.5〜41.8\%（術式（3））となり, 術式(2)及び街式(3)炕よる $\mathrm{Ti}$ 值低下萃は夫及 -20.5〜ー18.5\%及びー61.5〜ー58.2\%とな る.

(3) 定量値と原理との関係

第 4 表飞示す如く，術式，反忍時間，測定 方法を同じくする $\mathrm{Ti}$ 值は原理(1)飞比し原理 (2)飞於いて常飞低値を示す。術式(1)，術式(2)， 街式(3)の 2 時間值飞就いて原理(1)又は原理(2) そよる Stufo - 值に対する其の他の Ti 值の 百分比を求めると第 5 表 No. 2 及び No. 3 の 成績となり，原理(2)のStufo・値は原理 (1)の Stufo・值の $65.3 \sim 69.2$ \% 亿䢛ぎず, 原理(2) に於ける $\mathrm{Ti}$ 值低下率は $-34.7 \sim-30.8 \%$ と なる.

(4) 定量值と測定方法の関係

Stufo. 值飞対する比色値の百分比を第 5 表 No. 2 及び No. 3 の成績から術式 (1)，術式 (2), 術式(3)の 2 時間值飞就いて求めると 105.8 〜 114.3 \% (原理 (1)) 及び $28.5 \sim 30.3 \%$ （原理(2)）となり，原理(1;ては比色值はStufo. 值飞比し平均約10\%の高檤を示すに過ぎない が，原理(2)では比色值は著しい低值を示し， 其の低下率はー71.5〜ー69.7\%に達する事と なる。

(5) Farbkurve

各術式に於ける代表例（箺験番号 No.1 及 び No.11）の原理 (1) 及び原理 (2) 飞於ける Farbkurve 悌 8 笛，第 9 図江見る如く，原 理(1)飞於ける No. 1 が最も不定型的で S 57 附近で著明飞吸光す。各術式共, 原理(1)飞於 ける No.11 は Ti の定型的 Farbkurve K近 似するが， S 43で最もよく吸光す，原理(2)反 於ける Farbkurve は何れるTiの対発烟塩酸 呈色反応飞於ける定型的曲線に近似する.

(6)脱水「ク」浸の色調

第 4 表江示す如く，脱水「ク」浸の色崕は

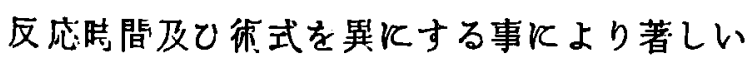
変化があり，理椧上赤裩色となるへき脱水
「ク」浸の色調は反心洔間を 10 分以内に短縮 すると，反応時間の短縮に伴い青色乃至柴色 色䛯が混色として濃厚に出現し，各術式とも 原理(1)反よる比色は遂に不可能となる，就中 術式(2)では反応時間を 1 時間とするる尚招柴 色色䛯が出現するが術式(1门び術式(3)では反 応时間 1 時間以上で脱水「ク」浸の色調は 何れすTi の固有色飞類似の色調となる.

実䀦 2. 㟫藤氏規準液の評価飞就いて

\section{実 略 方 法}

種々なる既知浱度度の遠藤氏規染液 ${ }^{21}$ 飞就 いて $10 \mathrm{~mm}$ 液層で定型的 Farbkurve 及び比 吸光倍数を測定し，其の成績を Ti「ク」溶 液の原理 (2)飞よる定型的 Farbkurve 及び比 吸光係数と比較して速藤氏規準液の色調及び 力価を検定した.

\section{実 験 成 綂}

成績は第10㘝，第 6 表，第11図の如し。

(1) 定型的 Farbkurve

第 10 図に示す如く，遠藤氏規準液並びに Ti「ク」溶液の原理(2)飞於ける色調の定型的 Farbkurve は相互飞甚だ近似する，但し前者 はS53で，後者はS57で最もよく吸光する点 が稍々異なる。

(2) 此吸光係数

第 6 表の透過率測定成結から遠藤氏規準液 の吸光度曲線を求めると第 11 四に示す如く, 蒸藤氏規汻液の濃度 C（mmg％青藍）山 Lambert-Beer の法則に従い次式で算出され る.

$$
\begin{aligned}
& \mathrm{C}=\mathrm{E} \times 0.34(\mathrm{~S} 53) \\
& \mathrm{C}=\mathrm{E} \times 0.36(\mathrm{~S} 57)
\end{aligned}
$$

即ち崒滕氏規準液の比吸光係数は青監濃度 に於いては0.34（S 53）及び0.36（S 57） と なる故に，之れに2.13を乘じて Ti 濃度に換 算すると，其の比吸光係数は夫々 0.724 ( $\mathrm{S}$ 53）及び0.776（S 57）となり，之れを Ti「ク」 溶液の原理(2)飞於ける比吸光係数（第 2 章, 第 2 项参照) 飞対比するとS 53では $1: 3.73$ (製出 $\mathrm{Tj}$ ) 及び $1: 3.57$ (合成 $\mathrm{Ti}$ )， $\mathrm{S} .57$ で 
は 1:3.19（製出 $\mathrm{Ti}$ ) 队び $1: 3.08$ (合成 Ti）となり前者は後者の約 $1 / 3$ (S 53) 及び 1/3.6（S57）となる.

第 6 表 透過率測定成結(蚞藤氏規潐液)

\begin{tabular}{|c|c|c|}
\hline 濃度 & 透過 & 率 D名 \\
\hline mg $\%$ Indigo & S. 57 & S. 53 \\
\hline 0.5 & 4.3 & 3.2 \\
\hline 0.45 & 5.8 & 4.8 \\
\hline 0.4 & 8.0 & 7.2 \\
\hline 0.35 & 10.8 & 9.3 \\
\hline 0.3 & 14.0 & 12.5 \\
\hline 0.25 & 20.0 & 18.0 \\
\hline 0.2 & 27.5 & 26.0 \\
\hline 0.15 & 38.0 & 36.0 \\
\hline 0.1 & 51.0 & 49.5 \\
\hline 0.075 & 61.5 & 59.0 \\
\hline 0.05 & 72.5 & 70.0 \\
\hline 0.025 & 85.0 & 83.0 \\
\hline 0.0125 & 92.0 & 90.0 \\
\hline 0.005 & 97.0 & 96.0 \\
\hline 照 & 100.0 & 100.0 \\
\hline
\end{tabular}

第10図 遠藤氏規渒液の Farbkurve：

(OD. OH Ti「ク」谘液の原理 (2)の

Farbkurveを示す)

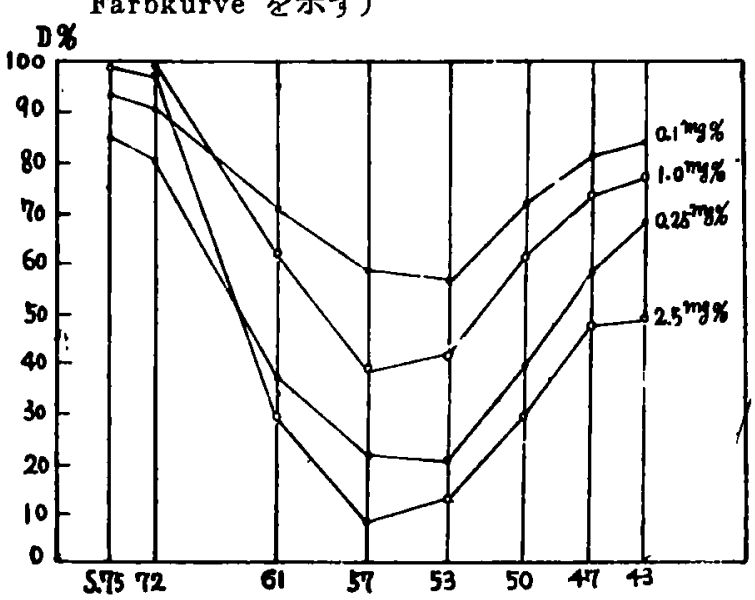

第11図 遠藤氏液の吸光度曲線

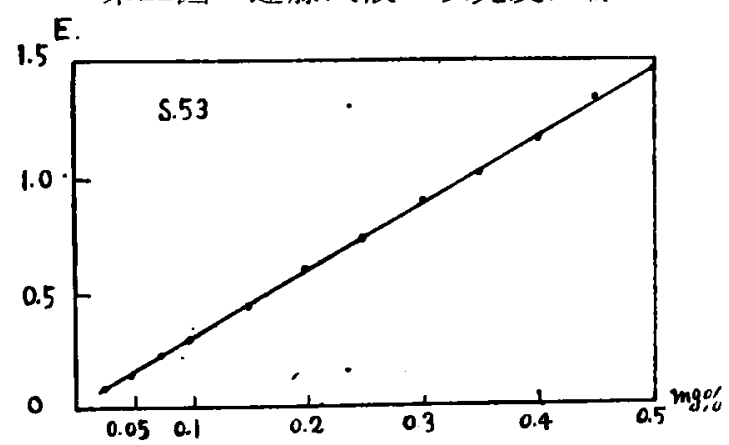

実臨 3. 各種酸化剂の評価に就いて

実 験 方 法

10 杼類の酸化剂即ち竹内氏試薬，0.5\% Obermayer's 試薬，5１0％塩素酸カリ液, 1096 硫酸銅夜，496クロールカルク水，1５ 96 過硫酸アンモン液, $3 \%$ 過酸化水素水, 及び 296 亜硝酸ソーダ夜のチモール・インドオキ ンル縮合郕としての優劣を評価せんとして被 検尿 No. 2 を使用し，竹内氏試薬は術式 (1), Obermayer's 試薬は術式(3)により，其他の酸 化剂は術式(1)の竹内氏試薬に代るに各種酸化 剂の $0.2 \mathrm{cc}$ を加文，従つて「ク」浸中の沃度 の中和を省略せる術式(1)火よりて得たる第 1 回色素抽出脱水「ク」浸 $6 \mathrm{cc}$ 飞就いて，原理 (1)及び原理(2)による Farbkurve 及び Stufo・ 値を測定した。試験例は各種酸化剤に就き 2 例宛とし，竹内氏試薬及び重硝酸ソータに対 する対照例は尿に代るに蒸渵水を使用せり。

\section{実 医，成 繶}

成績は第 7 表，第 12 図，第 13 図，第 14 図， 第15図の如し。

(1) $\mathrm{Ti}$ 值

原理(1)飞よる最高值は $2 \%$ 亜硝酸ソータに よる $30.23 \mathrm{mg} 96$ ，次で竹内氏試薬による $20.40 \mathrm{mg} \%$ \% $5 \%$ 塩素酸カリ液化よる 11.40 $\mathrm{mg} \% ， 0.5 \%$ Obermayer's 試薬による $9.08 \mathrm{mg}$ \%の順となり，10\%硫酸銅液飞よる $5.93 \mathrm{mg}$ 96が最低併を示した。

原理 (2)飞よる最高值は竹内氏試薬による $11.59 \mathrm{mg} \%$ で, $10.09 \mathrm{mg} \%$ (2 \%6亜硝酸ソー 夕液)，5.89mg\%（0.5\% Obermayer's 試薬） の順となり，1.54 mg\%（5 \%6塩素酸カり液） が最低值を示した。

対照例飞於いては竹内氏試楽では色素形成 は認めず，2 \%亜硝酸ソータ液では黄赤色の 色素形成があり，之を $\mathrm{Ti}$ と仮定して 17.68 $\mathrm{mg}$ 名(原理(1)) 及び $3.34 \mathrm{mg} \%$ （原理(2)）を 測定し得た。

原理(1)及び原理(2)反よる $\mathrm{Ti}$ 值の不一致は， 何れの酸化戍飞よるも常見され且つ原理(2)K 
於いて低值を示すが，其の $\mathrm{Ti}$ 值低下率は酸 化刜の種類によりて異なる。

第 7 表から酸化郕別に夫々原理(1)及び原理

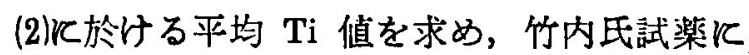
よる平均 $\mathrm{Ti}$ 值に対する其他の酸化削による 平均 $\mathrm{Ti}$ 值の百分比亚びに各㮔酸化郕に於け る原理(1)の平均 $\mathrm{Ti}$ 值飞対する原理(2)の平均 $\mathrm{Ti}$ 值の百分比を算出すると第 8 表の成績と なる。

(2) Farbkurve

原理(1)Kよる Farbkurve は第12図, 第13 図の如く，塩素酸カリを使用した No.5，No.7 及び亜硝酸ソータを使用した No. 17，対照例 No. 21 亿於いて非定型的である. 其他の酸化 郕飞よる場合は何れる概ね $\mathrm{Ti}$ の定型的 Farbkurve に近似するがS 43で最るよく吸光する 点が異なる.

原理(2)Kよる Farbkurve は第 14図，第 15 図の如く，5 名塩素酸力りを使用した No. 5, 亜硝酸ソータを使用したNo. 17 及び対照例 No. 21 飞於いて非定型的である他は概ねTiの 原理(2)飞於ける定型的 Farbkurve飞近似する。

第 7 表

各種酸化羭による Ti. 值 $\mathrm{mg} \%$ 測定成績

\begin{tabular}{|c|c|c|c|}
\hline \multirow{2}{*}{ 酸 } & \multirow{2}{*}{$\begin{array}{ll}\text { 試 験 } \\
\text { 番 号 }\end{array}$} & \multicolumn{2}{|c|}{ 定量 原理 } \\
\hline & & $\begin{array}{c}\text { (1) } \\
\text { S. } 47\end{array}$ & $\begin{array}{c}\text { (2) } \\
\text { S. } 57\end{array}$ \\
\hline \multirow{2}{*}{ 竹 内 氏 試 楽 } & No. 1 & 20.40 & 11.59 \\
\hline & 2 & 19.88 & 11.36 \\
\hline \multirow{2}{*}{ 0.5\% Obermeyer 氏試楽 } & 3 & 8.77 & 5.38 \\
\hline & 4 & 9.08 & 5.89 \\
\hline \multirow{2}{*}{5 电 塩 素 酸 カ リ } & 5 & 10.13 & 1.73 \\
\hline & 6 & 11.40 & 1.54 \\
\hline \multirow{2}{*}{1 \% 塩素酸 カ リ } & 7 & 7.65 & 3.23 \\
\hline & 8 & 7.20 & 2.96 \\
\hline \multirow{2}{*}{10 名 硫 酸 銅 } & 9 & 5.93 & 3.38 \\
\hline & 10 & 5.78 & 3.45 \\
\hline \multirow{2}{*}{$4 \mathscr{6}$ クロル力ルク } & 11 & 6.23 & 3.30 \\
\hline & 12 & 6.45 & 3.56 \\
\hline \multirow{2}{*}{$5 \%$ 過硫酸アンモン } & 13 & 8.63 & 5.06 \\
\hline & 14 & 8.69 & 4.95 \\
\hline \multirow{2}{*}{1 名過硫酸アンモン } & 15 & 8.40 & 4.88 \\
\hline & 16 & 7.20 & 4.28 \\
\hline \multirow{2}{*}{2 名覀硝酸ソータ } & 17 & 28.73 & 9.64 \\
\hline & 18 & 30.23 & 10.09 \\
\hline \multirow{2}{*}{3 \% 過 酸 化 水 新 } & 19 & 6.68 & $3 . \overline{38}$ \\
\hline & 20 & 6.60 & 3.30 \\
\hline \multirow[t]{2}{*}{ 対照(重硝酸ソータ) } & 21 & 17.18 & 2.14 \\
\hline & 22 & 14.85 & 3.34 \\
\hline \multirow{2}{*}{ 対照（竹内氏試 楽） } & 23 & 0 & 0 \\
\hline & 24 & 0 & 0 \\
\hline
\end{tabular}

第 8 表

各醒酸化剂化上る平均 Ti. 值百分比 (\%)

\begin{tabular}{|c|c|c|c|c|}
\hline \multirow[t]{2}{*}{ 酸化、丳 } & \multicolumn{2}{|c|}{ 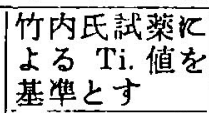 } & \multicolumn{2}{|c|}{$\begin{array}{l}\text { 原理(1)によ } \\
\text { るTi.值を } \\
\text { 基準とす }\end{array}$} \\
\hline & $\begin{array}{l}\text { 原理 } \\
\mathrm{S} .2\end{array}$ & \begin{tabular}{|l|} 
\\
S. 理(2) \\
S. 57
\end{tabular} & $\begin{array}{l}\text { 原理(1) } \\
\text { S. 47 }\end{array}$ & $\begin{array}{l}\text { 原理(2) } \\
\text { S. } 57\end{array}$ \\
\hline 竹 内 氏 試 薬 & 100.0 & 100.0 & 100.0 & 57.0 \\
\hline $\begin{array}{l}0.5 \% \text { Obermeyer 氏 } \\
\text { 試楽 }\end{array}$ & 44.3 & 49.0 & 100.0 & 63.0 \\
\hline 5 名塩素酸カリ & 53.5 & 14.2 & 100.0 & 15.2 \\
\hline 1 名塩菜酸力リ & 37.0 & 27.0 & 100.0 & 42.0 \\
\hline 10 \% 硫 酸 銅 & 29.0 & 30.0 & 100.0 & 56.6 \\
\hline 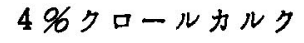 & 31.4 & 30.0 & 100.0 & 54.1 \\
\hline $5 \not 6$ 過 & 43.0 & 43.5 & 100.0 & 59.0 \\
\hline 1 台過硫酸アンモン & 38.7 & 40.0 & 100.0 & 58.7 \\
\hline 29 亜硝酸ソータ & 146.4 & 86.0 & 100.0 & 33.5 \\
\hline 3 \% 過酸化水素 & 33.0 & 21.0 & 100.0 & 50.0 \\
\hline
\end{tabular}

第 12 図

各種酸化刘に於ける Farbkurve (原理 (1))

$\left(\begin{array}{ll}\text { No. } 1=\text { 竹内氏試薬 } & \text { No. } 7=196 \text { 塭菜酸カリ } \\ \text { No. } 3=\text { Obermeyer's 試楽 No. } 9=1096 \text { 硫酸銅 } \\ \text { No. } 5=596 \text { 掹菜酸カリ }\end{array}\right)$

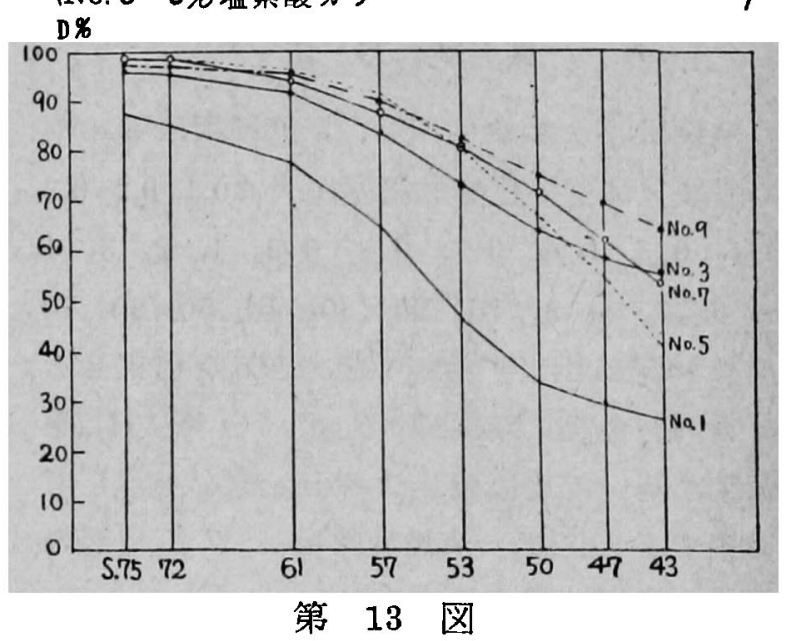

各㮔酸化剂に於ける Farbkurve (原理 (1))

No.11=4و6クロールカルク No.17=296亜硝酸ソータ

No.13=5\%過硫酸アンモン No.19=3\%過酸化水素

No.15=10\%過硫酸アンモンNo.21=西硝酸ソータ対照

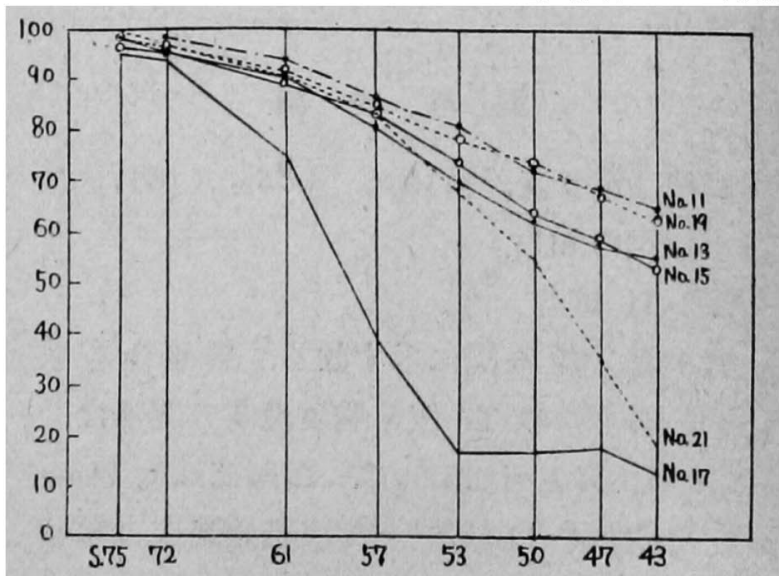


第 14 図

各種酸化郕に於ける Farbkurve（原理 (2))

$\left(\begin{array}{l}\text { No. } 1=\text { 竹内氏試薬 } \quad \text { No. } 7=1 \% \text { 塩菜酸カリ } \\ \text { No. } 3=\text { Obermeyer's 試薬No. } 9=10 \% \text { 硫酸銅 } \\ \text { No. } 5=5 \% \text { 塭菜酸カリ }\end{array}\right)$

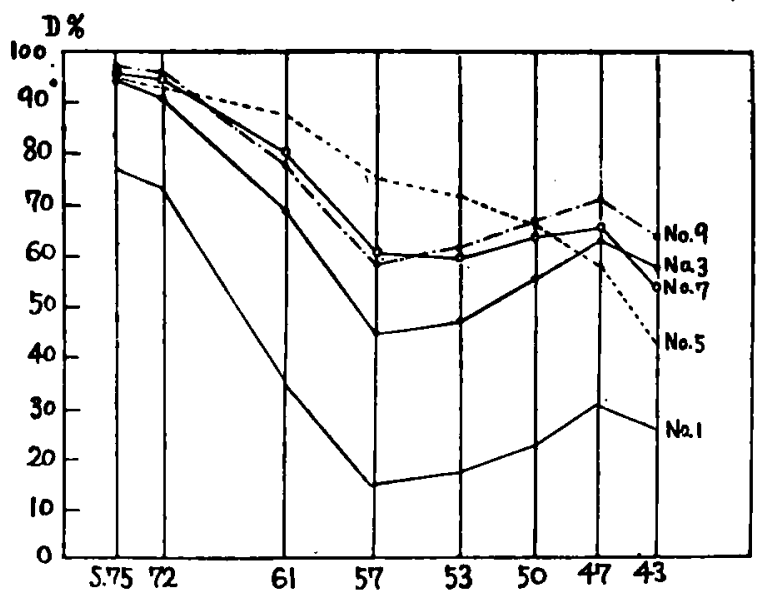

実䀦 4. 被検尿中醋酸並びに三塩化醋酸濃 度の定量值に及ほす影響に就いて。

A 原理(1)Kよる $\mathrm{Ti}$ 值比較実験

\section{実 䀦方 法}

被検尿 $\mathrm{No} .3$ を使用し，5倍稀釈尿 $5 \mathrm{cc}$ 中 の醌酸又は三塩化酷酸濃度が夫々 $0.1,0.2,0.3$, $0.4,0.5,0.6,0.7,0.8,0.9,1,2,3,4$, $5,6,7,8,9,10,20,30,40,50,60,70$, 及び $80 \%$ に相当する如く滤尿 Icc を稀釈せる 対照例を含む試験例27例飞就いて, 術式(1), 原 理(1)飞基いて比色值及び Stufo. 值を測定して 比較すると共に，洗液分離量，「ク」浸層の 容量, 及び $\mathrm{V}$ 量を測定した.

Farbkurve は代表例（0.5\%及び 80\%の酸 含有例）飞就いて測定し, 脱水「ク」浸総量 は 7cc（第 1 回抽出）及び $4 \mathrm{cc}$ (第 2 回抽出） とせり.

\section{実殹成 挠}

成績は第 9 表，第10表，第16図，第17図及 び第18図の如し.

(1) $\mathrm{Ti}$ 值

第 9 表，第 16 図に示す如く，醋酸含有尿 （尿!と略す）の $\mathrm{Ti}$ 值と醋酸港度の関係は， Stufo. 値（第 1 回油出）では 10\%迄注約 $14 \mathrm{mg}$

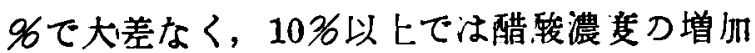

第 15 図

各種酸化剤に於ける Farbkurve（原理 (2)）

No.11=4\%クロールカルク No.17=2\%亜硝酸ンータ No. $13=5 \%$ 過硫酸アンモン No.19=3\%過酸化水菜 No.15=1\%過硫酸アンモン No.21＝亜硝酸ソータ対照

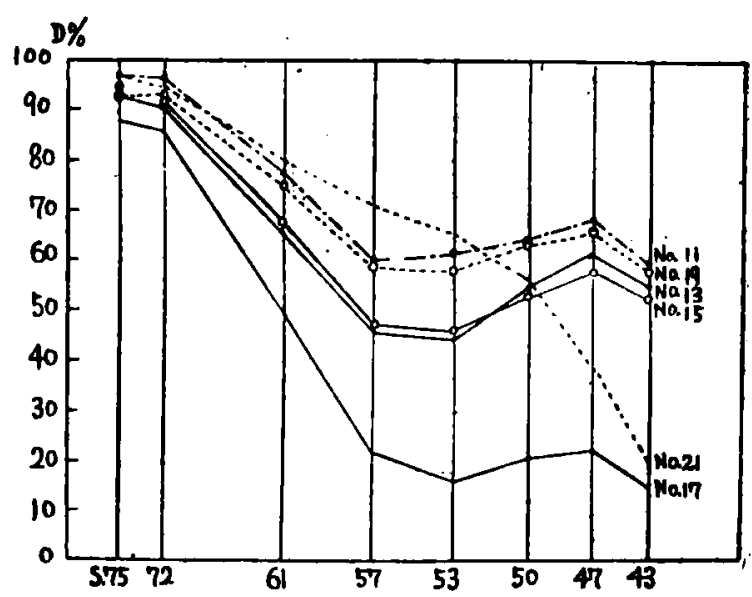

と共に Ti 值は低下し80\%で最低值を示す。 比色值に於いてす同様であるが比色值は Stuto. 值飞比乙約 5960 增強を示す（但し醋 酸濃度 $20 \%$ 迄）。然し乍ら尿の Stufo. 值（第 1 回抽出十第 2 回抽出）は0.2 -5\%間で高值 を示して大差なく，196て最高值 $17.28 \mathrm{mg} \mathscr{\%}$ を示す。

三塩化醋酸含有尿（尿 3 と略す）の $\mathrm{Ti}$ 值と 三塩化醋酸濃度の関係は, Stufo. 值（第 1 回 抽出）では $1 \%$ 迄は三塩化醋酸濃度の増加と 洪に急激に增大し，1\%以上は除々飞增大の 傾向を示すが 1 - 10\%間で 19２0mg \%の高 值を示して大差なく，20～80\%間で稍々低值 を示した．比色值は $10 \%$ 迄は Stufo. 值と同 様の関係を示すが，10\%以上では帨水「ク」 浸の色調は比色飞適せず40\%以上では全く比 色不能となつた。 然して比色值は Stufo. 值 飞比し約 $10 \%$ の增強を示す（尿中三塩化醌酸 濃度 $10 \%$ 迄).

尿3 の Stufo. 值（第 1 回抽出＋第 2 回抽出） は1〜10\%間で何れる約 $21 \mathrm{mg} \%$ の高值を示 して大差なく，9\%で最高值 $21.64 \mathrm{mg}$ \%を示 した。

尿, 及び尿 3 亿於ける平均 $\mathrm{Ti}$ 值 (1 10 \% 間)の百分此を求めると尿、に於いて $+36.3 \%$ (Stufo. 值, 第 1 回抽出) 及び $+46.5 \%$ (比 
第 9 表 醋酸並びそ三塩化醋酸含有尿に於ける Ti. 值及び V.量測定成績

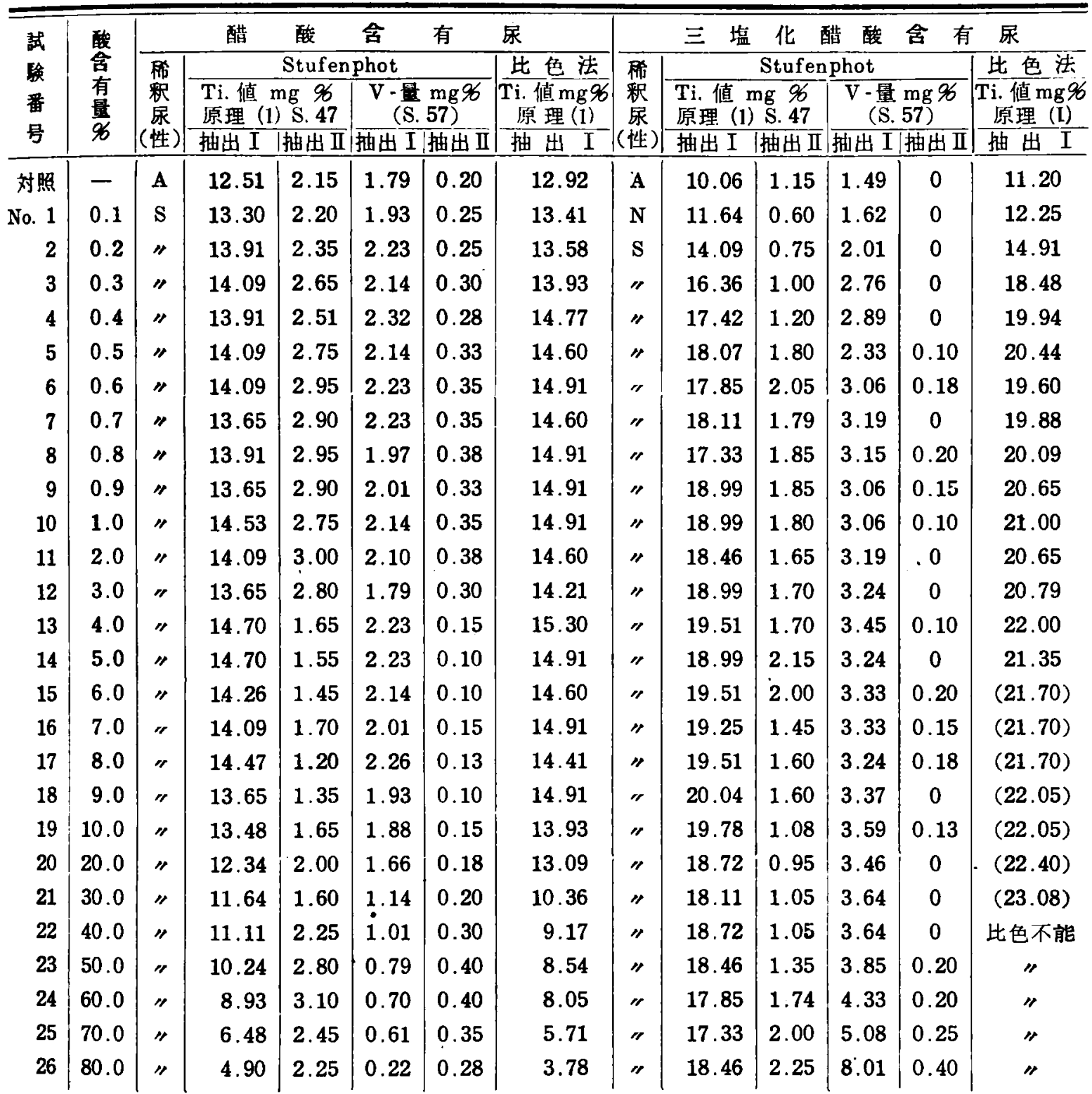

第 16 図

醋酸並びに三塩化醋酸含有尿飞於ける Ti. 值 $m g \%$ 比輍成績（第 1 回抽出，原理 (1)) $(\mathrm{C}=$ 比色值, $\mathrm{S}=$ Stufo. 值, $\mathrm{V}=\mathrm{v}$. 量 $)$ $($ 尿 1 醋酸含有尿，尿 $3=$ 三程化醋酸含有尿 $)$

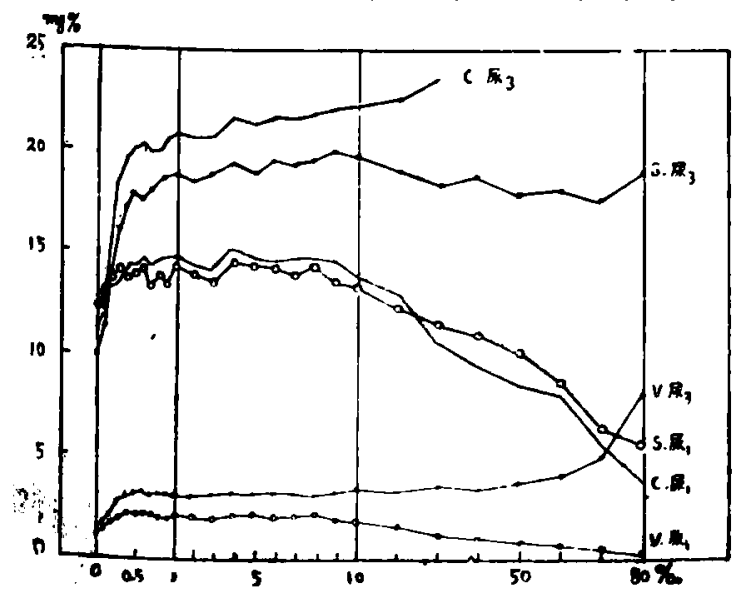

第17図 Farbkurve（原埋(1)）

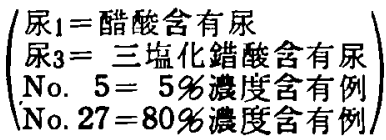

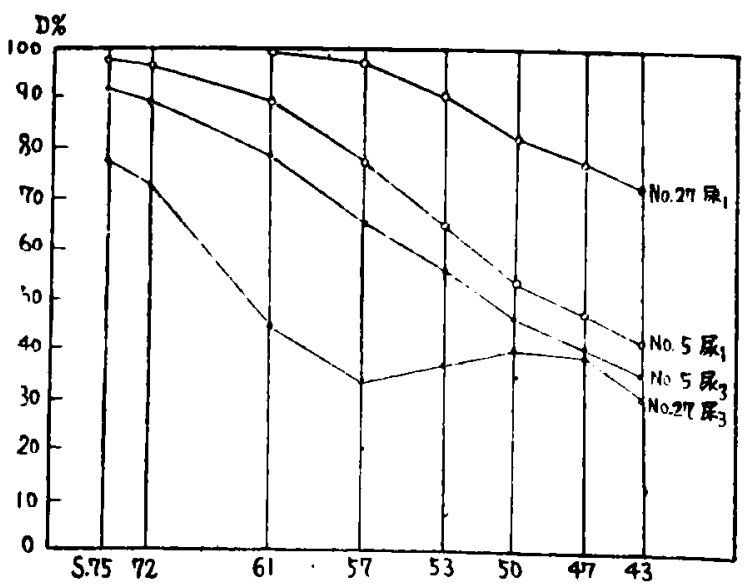


第 18 図

分離洗液量及び「ク」浸層容量の增量曲線 $\left(\begin{array}{l}\text { 尿 } 3=三 \text { 三塩化醋酸含有尿 } \\ \text { 尿 } 1=\text { 醋酸含有尿 }\end{array}\right)$

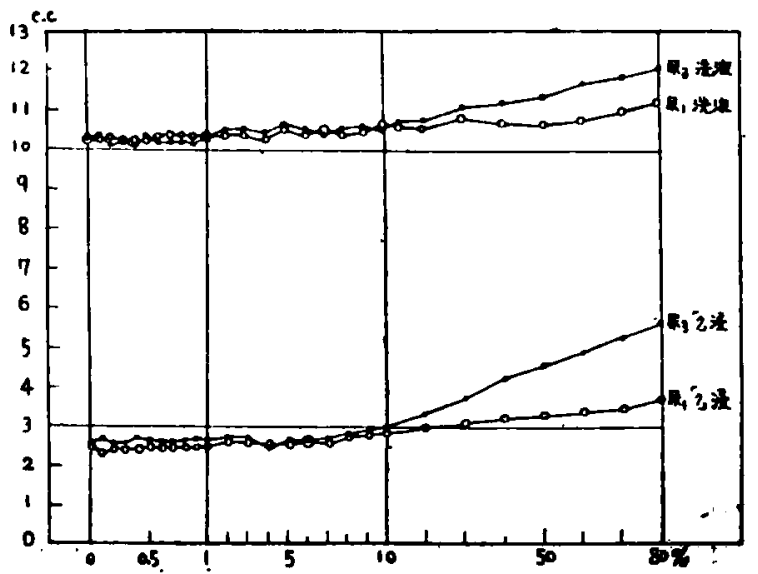

色値，第 1 回抽出)の増強となり, 最高 Stufo. 值（第 1 回抽出十第 2 回抽出）の百分比は尿3 飞於いて +25.2\%の増強となる。

（2）脱水「ク」浸の色調と Farbkurve

第10表に示寸如く，尿、に於ける脱水「ク」 浸の色調は赤褐色一黄赤色で全例を通じ Ti の固有色と同類色となるも，尿了では三塩化 酷酸濃度 $5 \%$ 迄は赤褐色なるも，三䘏化醋酸 濃慢の增加と共飞暗赤褐色となり $20 \%$ 以上で は紫色色調が混色として出現し80\%灾と於ける 脱水「ク」浸の紫色色調は最も濃厚であり， 紫色色調の出現する脱水「ク」浸では特殊の エステル様芳香を認める．Farbkurve は第17 図に六㧊如く，尿1では何れる概ね $\mathrm{Ti}$ の定 型的 Farbkurve に近似するもS 43 で最もよ く吸光する点が稍々買り，尿 3 では $0.5 \%$ 告化醋酸含有例 No. 5 は概就定型的となるが, $80 \%$ 三塭化醒酸含有例 No. 27 では著しく非 定型的で $S$ 57附近で著明に吸光した。

\section{(3) $V$ 量}

第 9 表，第 16 図に示す如く，尿 3 亿於ける $\mathrm{V}$ 量は被検尿中三塩化醋酸濃度の増加と共飞 增量し $80 \%$ で最高值 $8.41 \mathrm{mg} \%$ （第 1 回抽出 十第 2 回抽出）を示し $1 \sim 10 \%$ 間の平均 $\mathrm{V}$ 量 $3.5 \mathrm{mg} 9 \%$ 約 2.4 倍飞相当す．尿、に於け る V 量は脱水「ク」浸飞紫色色調の出現を認 めざるとより之を真のV量とは認め得ない。
第 10 表

醋酸亚びに三塩化醋酸含有永に於ける酸 含有量と脱水「ク」浸の色調，「ク」浸層の 容量及び分離洗液量の関係

脫水「ク」浸の色調二第 1 回抽出時.

「ク」浸層の容量二第 1 回抽出時

分雖 洗 没 量=第 1 回及び第 2 回分離 洗液の総計

尿 1 二醋酸含有尿， 尿 3 二三塩化醋酸含有尿

\begin{tabular}{|c|c|c|c|c|c|c|c|}
\hline \multirow{2}{*}{$\begin{array}{c}\text { 試 } \\
\text { 験 } \\
\text { 番 } \\
\text { 号 } \\
\end{array}$} & \multirow{2}{*}{ 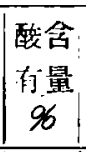 } & \multicolumn{2}{|c|}{$\begin{array}{c}\text { 脫水「ク」浸 } \\
\text { の色調 } \\
\end{array}$} & \multicolumn{2}{|c|}{ 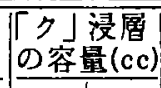 } & \multicolumn{2}{|c|}{$\begin{array}{c}\text { 分離洗液量 } \\
(\mathrm{cc})\end{array}$} \\
\hline & & 尿 1 & 尿3 & 尿1 & 尿3 & 烁1 & 尿3 \\
\hline 齐照 & 0 & 赤黄褐 & 赤黄褐 & 2.45 & 2.50 & 10.30 & 10.30 \\
\hline No. 1 & 0.1 & $"$ & $"$ & 2.35 & 2.35 & $"$ & 10.35 \\
\hline 2 & 0.2 & " & $"$ & 2.40 & 2.50 & 10.35 & 10.15 \\
\hline 3 & 0.3 & " & 赤褐 & $"$ & $"$ & 10.30 & 10.30 \\
\hline 4 & 0.4 & $"$ & $"$ & " & 2.65 & $"$ & 10.20 \\
\hline 5 & 0.5 & $"$ & $"$ & 2.45 & 2.60 & $"$ & 10.35 \\
\hline 6 & 0.6 & " & $r$ & $"$ & " & 10.45 & $"$ \\
\hline 7 & 0.7 & $"$ & $"$ & $"$ & $"$ & " & 10.30 \\
\hline 8 & 0.8 & $"$ & " & 2.40 & 2.55 & 10.40 & 10.40 \\
\hline 9 & 0.9 & $"$ & " & 2.45 & 2.70 & $"$ & $10: 35$ \\
\hline 10 & 1.0 & $"$ & $"$ & " & 2.60 & " & 10.40 \\
\hline 11 & 2.0 & $"$ & $r$ & 2.60 & 2.70 & " & 10.60 \\
\hline 12 & 3.0 & " & " & " & " & $"$ & 10.55 \\
\hline 13 & 4.0 & $"$ & $"$ & 2.55 & 2.50 & 10.30 & 10.50 \\
\hline 14 & 5.0 & $"$ & 暗赤裼 & 2.50 & 2.60 & 10.55 & 10.60 \\
\hline 15 & 6.0 & $"$ & $"$ & 2.60 & 2.65 & 10.40 & 10.50 \\
\hline 16 & 7.0 & $"$ & $"$ & 2.50 & 2.60 & 10.55 & " \\
\hline 17 & 8.0 & $"$ & $"$ & 2.70 & 2.80 & 10.40 & 10.55 \\
\hline 18 & 9.0 & $"$ & $"$ & $"$ & "r & 10.50 & $"$ \\
\hline 19 & 10.0 & " & $"$ & 2.80 & 2.95 & 10.65 & 10.60 \\
\hline 20 & 20.0 & $"$ & $\left|\begin{array}{c}\text { 暗赤褐 } \\
\text { 微紫 }\end{array}\right|$ & 3.00 & 3.25 & 10.55 & 10.75 \\
\hline 21 & 30.0 & $"$ & $"$ & 3.10 & 3.65 & 10.75 & 11.15 \\
\hline 22 & 40.0 & $"$ & $\mid$ 暗赤褐 & 3.20 & 4.20 & 10.70 & 11.20 \\
\hline 23 & 50.0 & 淡黄赤 & $"$ & $"$ & 4.50 & $r$ & 11.40 \\
\hline 24 & 60.0 & $r$ & " & 3.30 & 4.80 & 10.80 & 11.65 \\
\hline 25 & 70.0 & " & " & 3.40 & 5.20 & 11.00 & 11.75 \\
\hline 26 & 80.0 & " & 暗紫赤 & 3.60 & 5.50 & 11.20 & 12.10 \\
\hline
\end{tabular}

\section{（4）「ク」浸層の容量及び洗液分離量.}

第 10 表, 第 18 図江示す如く,「ク」浸層の 容量は被検尿中醋酸又は三塩化醋酸濃度 $5 \%$ 附近以上から醋酸又は三塩化醋酸濃度の增加 と共に著明に增量し，80\%飞於いて最大量を 示し 0.5 吕附近の「ク」浸層の容量飞比し約

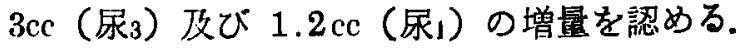


洗液分離量（第 1 回洗液+第 2 回洗液）の

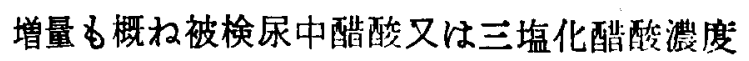
の増加と共に増量し，80\%で最大量を示し理 論値量 $10 \mathrm{cck}$ 比し約 $2 \mathrm{cc}($ 尿3）及び $1 \mathrm{cc}$ (尿1） の増量を認める。

B. 原理(1)及び原理(2)による $\mathrm{Ti}$ 值比較実験

\section{実 臨 方 法}

被検尿 No. 4 を使用し，5倍稀釈尿 $5 \mathrm{cc}$ 中 の醋酸濃度が夫々 $0.5,1 ， 5,10,20,40$ 及 び8096に相当する如く滤尿 1cc を稀釈せる対 照例を含む試験例 8 例に就いて術式(1)，原理 (1)及び原理 (2) 飞基いて Stufo. 值を測定して 比較した。色素抽出は第 1 回のみとし，脱水 「ク」浸は6ccとした。

\section{実 験 成 績}

実験成績成績は第11表，第19図に示す如く， 原理(1)による $\mathrm{Ti}$ 值は尿 1 では 0.5 10\%閏 で最高值（約 $6 \mathrm{mg} \%$ ）を，尿 3 では 10〜40 \%間で最高値（約 $10.3 \mathrm{mg}$ 它）を示し尿 3 の 最高 Ti 值は尿 1 の其れに比し約 $70 \%$ の堌強 を示す。

原理 (2) Kよる Ti 值は尿1では 0.5〜5\% 間で最高值（約 $3.5 \mathrm{mg}$ 兑）を示し，尿 3 では 10 40\% 間で最高值（約 $4 \mathrm{mg} \%$ ）を示す。 1〜80\%間で大差を認めない.

第11表 醋酸並びに三塭化醌酸含有尿に 於ける Ti. 值比較測定成績

尿 1 二醋酸含有尿

尿 $3=$ 三塩化醋酸含有尿

\begin{tabular}{|c|c|c|c|c|c|}
\hline \multirow{3}{*}{$\begin{array}{c}\text { 試 } \\
\text { 毺 } \\
\text { 番 } \\
\text { 号 }\end{array}$} & \multirow{3}{*}{$\begin{array}{l}\text { 酸 } \\
\text { 含 } \\
\text { 有 } \\
\text { 量 } \\
\text { (q6) }\end{array}$} & \multicolumn{4}{|c|}{ Ti. 值 (mg $\mathscr{6})$} \\
\hline & & \multicolumn{2}{|c|}{$\begin{array}{l}\text { 原 } \\
\text { S. } 47\end{array}$} & \multicolumn{2}{|c|}{ 原 $\mathrm{S}, 57$} \\
\hline & & 康 1 & 属3 & 尿 1 & $\mathrm{~F} 3$ \\
\hline 対照 & 0 & 5.55 & 5.63 & 2.96 & 3.00 \\
\hline No, 1 & 0.5 & 6.08 & 7.80 & 3.49 & 3.38 \\
\hline 2 & 1.0 & 6.00 & 8.18 & 3.60 & 3.56 \\
\hline 3 & 5.0 & 6.00 & 8.78 & 3.40 & 3.71 \\
\hline 4 & 10.0 & 5.93 & 9.98 & 3.38 & 4.00 \\
\hline 5 & 20.0 & 5.33 & 10.43 & 2.89 & 4.08 \\
\hline 6 & 40.0 & 4.95 & 10.43 & 2.78 & 4.00 \\
\hline 7 & 80.0 & 3.35 & 8.90 & $1.7 \dot{3}$ & 3.45 \\
\hline
\end{tabular}

尿 1 贝ひび尿 3 の最高 Ti 值を比䡆するに，尿 3

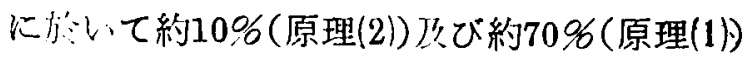
の增強となる。尿1及び尿3に於ける原理(1)の $\mathrm{Ti}$ 值は原理 (2)の其れに比し常に高値を示し, 原理(1)の $\mathrm{Ti}$ 值に対する原理 (2)の $\mathrm{Ti}$ 值低 下率を最高 $\mathrm{Ti}$ 值に就いて求めると $-60 \%$ （尿3）及び $-42 \%($ 尿) となる。

\section{第 19 図}

醋酸並びそ三塩化醋酸含有尿に於ける Ti. 值 $\mathrm{mg} \%$ 比較成績 (第 1 回抽出, 原理(1)), 原理(2)).

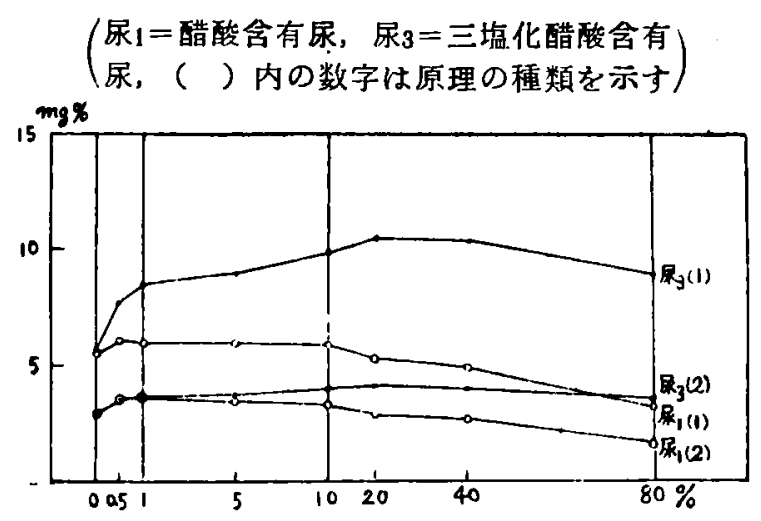

実験 5. 三塩化醋酸含有尿飞於ける定量 值とクロ、フォルム浸水洗の影 響に就いて

\section{実 験 方 法}

被検尿 No. 5 を使用乙，5倍稀釈尿 $5 \mathrm{cc}$ 中 の三塩化醁酸濃度が火夕 $0.5 ， 1 ， 5 ， 10 ， 20$, $30,40,50,60,70$ 及び $80 \%$ 飞相当する如く 㴽尿 $1 \mathrm{cc}$ を稀釈せる対临例を含む試駼例 12 例飞就いて，術式(1)及び術式(3)反より先づ水 洗 2 回の第 1 回色素抽出脱水「ク」浸 $6 \mathrm{cc}$ 作り（A 浸と略す), 其の3cck就いて原理 (1) 及び原理 (2) と基いて Stufo. 值及び V 量を測 定すると共に, 残余の A 浸 $3 \mathrm{cc}$ を水 $3 \mathrm{cc}$ で 3 回反覆水洗した後, 無水硫酸ソーダ $1 \mathrm{~g}$ を加 えた脱水「ク」浸を作り其の全量を $4 \mathrm{cc} と し$ (B浸と略す)，A浸に於けると同㥞の測定を し其の成績を比較した。但し原理(1)Kは S 47 及びS 50 を，原理 (2) そはS 57 及びS 53 を使 用し，Farbkurve は三塩化醋酸濃度 $0.5 \%$ 及 び80\%の代表例飞就いてのみ測定し，術式(1) によるA浸は「ク」浸中の沃度中和前後に各 
1 回㱜「ク」浸を水洗して之を作つた.

\section{実 倹 成 縤}

成績は第12表，第20図，第21図，第22図， 第23図に示す如し。

（1） $\mathrm{Ti}$ 值と「ク」浸水洗の関係

第12表，第20図，第21図飞示す如く，Ti 值 は「ク」浸を反婹水洗する事により著しく低 下し，其の低下率は尿中三塩化醌酸濃度の増 大するに伴い益々大となる，第12表から A 浸 の $\mathrm{Ti}$ 值に対する B 浸の $\mathrm{Ti}$ 值低下率を $0.5 \%$ ， $10 \%$ 及び $80 \%$ 三塩化醋酸含有例飞就いて求め ると，術式 (1)では夫々ー15\%，-25.8\%及 び -37.2\%（原理 (1)・S 47）又は $-11 \%$, $-11.4 \%$ 及び-38.3\%（原理(2)・S 57）とな り，街式(3)ではケタ-1.396，-15.7\%及び -41.996 (原理(1)・S 47) 又は+19, +1.5 96 及び-48.396（原理(2)・S 57）となる。然 して此の $\mathrm{Ti}$ 值低下率は原理(1) K S 50を, 原 理(2) K S 53 を夫々適用した $\mathrm{Ti}$ 值に就いて 算出すると其の低下率は更に人となり術式(1) では夫々 $-14.6 \% ，-25.29$ 及び $-55.7 \%$ （原理 (1). S 50）又は -7.8\%，-10.9\%及 びー45.196（原理 (2).S53), 術式(3)では夫 々 $-10.5 \%,-26.9 \%$ 及び-55.8\%（原理(1)。 S 50）又は+9.5\%，-7.1\%及び-54.7\% （原理(2)。S 53）となる。

（2） Ti 值と尿中三塩化醋酸濃度（\%）の 関係。

\section{a. A 浸の場合}

術式 (1)では 20\%濃度以上（原理 (1)）及び $30 \%$ 濃度以上（原理(2)）又術式(3)では $5 \%$ 濃 度以上 (原理(1)) 及び 10\%濃度以上 (原理(2)) の三塩化酷酸含有例飞於いては何れも三塩化 醋酸溇度の增加と共に $\mathrm{Ti}$ 值は著しく增大し， 80\%濃度飞於いて最高値を示す。10\%濃度に 於ける $\mathrm{Ti}$ 值に対する 8096 濃度飞於ける Ti 值の增大は術式(1)では約 1.4 倍（原理(1). $\mathrm{S}$ 47）又は1.7倍（原理(2)・S 57), 術式(3)では 約 4 倍（原理 (1)・S 47）又は 6.3 倍（原理(2)。 S 57）飞相当す.

b. B 浸の場合
術式(1)では尿中三塩化醋酸濃度の増加に伴 $3 \mathrm{Ti}$ 值の増大は原理 (1) 飞於いて僅か反其の 傾向を認めるが原理(2)では 0.5〜80\%莀度間 で $\mathrm{Ti}$ 值飞大差を認めず。術式(3)では原理(1) 及び原理(2)による $\mathrm{Ti}$ 值は共に10\%濃度以上 飞於いて三程化醋酸浱度の増加と共に増大し $80 \%$ 濃度飞於ける Ti 值は10\%洤度に於ける $\mathrm{Ti}$ 值の約 2.6倍（原理 (1)・S 47）又は約 3.2 倍（原理(2)・S 57）飞相当す。

(3) $\mathrm{Ti}$ 值と術式の関係

第12表，第20図，第21図飞示す如く，術式 (1)と術式(3)の Ti 值を比較するに, 三塩化醋 酸濃度及び原理を同じくする $\mathrm{Ti}$ 值は術式 (3) 飞於いて著しく低值を示し，其の Ti 值低下 率は 0.5 10 96濃度間で最も大きく，10\%濃 度以上では三坫化醋酸濃度の增加と其飞減少 す.

B浸に於いて術式(1)の Ti 值に対する術式 (3)の Ti 值低下率を夫々 $0.5 \%$ ，10\%及び 80\%濃度飞於ける Ti 值飞就いて算出すると 原理 (1)・S 47 ではー71.0\%，-62.6\%及び -18.5\%となり，原理(2)・S 57ではー75.7\%， $-70.7 \%$ 及びー19.3\%となる. 然して0.5〜 10\%間に於ける平均 $\mathrm{Ti}$ 值は術式 (3)では術式 (1)の約 1/3.5 K過ぎない.

(4) $V$ 量

第12表，第20図，第21図に示す如く，A浸

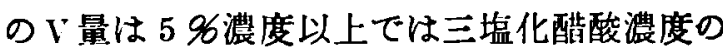
増加々共飞著明に（術式(1)）又は極めて著明 に（術式(3)）飞增量し $80 \%$ 濃度で最高値を示 し 10\%濃度に於ける V 量の約 3 倍（術式(1)） 又は 6.6 倍（術式(3)）飞相当す。 V量は「ク」 浸を水洗すると減少し，A浸のV量に対する B 浸のV 量の低下率を $10 \%$ 及び $80 \%$ 濃度に於 けるV量炕就いて算出すると夫々 $-27.9 \%$ 及 び $-66.0 \%$ (琎式 (1)) 又は $-20.0 \%$ 及び $-53.9 \%$ (術式(3)) となる。

B 浸に於けるV量は術式(1)では尿中三塩化 醌酸濃度 $10 \%$ 以上の試験例で軽度の增量を示 すが，術式(3)では著明に増量し，80\%濃度に 於ける V 量は $10 \%$ 濃度飞於ける V 量の約 1.4 倍（術式(1)) なると対し約 3.9 倍（術式(3)） 
となる。

\section{(5) Farbkurve}

原理(1)化よる Farbkurve は第22図，第23 図の如く，A浸の Farbkurve は試験例 No. 1 が両術式と Ti の定型的 Farbkurve に稍々 類似するが，試験例 No.11 は甚だしく非定 型的で S 53 で最も強く吸光し脱水「ク」浸 の色調が紫赤色なる事を示す，B浸の Farbkurve は両術式とも試験例 No. 1 が概ね定型 的曲線飞類似するが，試験例No. 11 では尚拉 非定型的で S 53〜S61 間で強く呚光し其の 色調は赤裮色と紫色の混色なる事を示してい る.

第 12 表 三塭化醌酸含有尿に於ける Ti. 值と脱水「ク」浸水洗の影響並び飞術式， 原理，三塩化醋酸含有量及び V. 量との関係

$(\mathrm{A}=\mathbf{2}$ 回水洗脫水「ク」浸 $\mathrm{B}=5$ 回水洗脫水「ク」浸 $)$
人尿を使用し，原尿及び原尿 $50 \mathrm{cc} に \mathbf{1 / 1 0}$ 容量及び $1 / 20$ 容量の $20 \%$ 醌酸鉛又は $20 \%$ 塩 基性醋酸鉛を加えて滤過したる清澄漟尿の各 Icc 飞就いて術式(1)，原理(1)及び原理(2)飞よ り Stufo・值亚びそ Farbkurve を測定すると 共江，各種清澄剂使用による沈澱中のインヂ カンを定量せんとして，沈澱に一定の処理を 加えたる抽出液 $5 \mathrm{cc}$ に就いて同様の測定をし た.

\begin{tabular}{|c|c|c|c|c|c|c|c|c|c|c|c|c|c|}
\hline \multirow{4}{*}{$\begin{array}{l}\text { 定 } \\
\text { 量 } \\
\text { 術 } \\
\text { 式 }\end{array}$} & \multirow{4}{*}{$\begin{array}{l}\text { 試 } \\
\text { 験 } \\
\text { 番 } \\
\text { 号 }\end{array}$} & \multirow{4}{*}{$\begin{array}{l}\text { 酸 } \\
\text { 含 } \\
\text { 有 } \\
\text { 量 } \\
(96)\end{array}$} & \multirow{4}{*}{$\begin{array}{c}\text { 稀 } \\
\text { 釈 } \\
\text { 原 } \\
\text { (性) }\end{array}$} & \multicolumn{8}{|c|}{ Ti. 值 (mg $\%)$} & \multirow{3}{*}{\multicolumn{2}{|c|}{$\frac{\text { V. 量(mg } \not h)}{\text { S. } 57}$}} \\
\hline & & & & \multirow{2}{*}{\multicolumn{2}{|c|}{\begin{tabular}{l}
\multicolumn{2}{c}{ 原 } \\
S. 47
\end{tabular}}} & \multicolumn{2}{|c|}{ 理 (1) } & \multicolumn{4}{|c|}{ 原 } & & \\
\hline & & & & & & S. & & \multicolumn{2}{|c|}{ S. 57} & \multicolumn{2}{|c|}{ S. 53} & & \\
\hline & & & & $\mathbf{A}$ & B & $\mathbf{A}$ & B & A & B & A & B & $\mathbf{A}$ & B \\
\hline \multirow{12}{*}{1} & 対照 & 0 & $\mathbf{A}$ & 11.55 & 11.20 & 10.88 & 9.50 & 5.59 & 4.50 & 6.26 & 4.80 & 1.98 & 1.70 \\
\hline & No. 1 & 0.5 & S & 15.08 & 13.50 & 13.58 & 11.60 & 6.68 & 5.95 & 6.86 & 6.40 & 2.63 & 2.20 \\
\hline & 2 & 1.0 & " & 15.53 & 12.70 & 13.58 & 11.30 & 6.86 & 5.80 & 6.98 & 6.30 & 2.59 & 2.05 \\
\hline & 3 & 5.0 & $"$ & 15.08 & 11.70 & 13.20 & 10.10 & 6.04 & 4.95 & 6.34 & 5.15 & 2.74 & 1.90 \\
\hline & 4 & 10.0 & $"$ & 15.53 & 11.50 & 13.43 & 10.50 & 5.58 & 4.95 & 5.74 & 5.15 & 3.19 & 2.30 \\
\hline & 5 & 20.0 & " & 15.08 & 12.70 & 14.03 & 10.90 & 5.89 & 4.65 & 5.93 & 5.05 & 3.98 & 2.40 \\
\hline & 6 & 30.0 & $"$ & 16.05 & 11.50 & 15.45 & 10.90 & 5.89 & 4.95 & 6.19 & 5.15 & 5.14 & 2.55 \\
\hline & 7 & 40.0 & " & 16.73 & 13.30 & 16.58 & 12.60 & 7.24 & 5.80 & 7.84 & 5.75 & 6.19 & $2.8 \dot{5}$ \\
\hline & 8 & 50.0 & $"$ & 19.58 & 13.90 & 22.28 & 12.40 & 8.78 & 5.85 & 9.60 & 6.10 & 7.54 & 2.90 \\
\hline & 9 & 60.0 & $"$ & 21.68 & 13.70 & 24.30 & 12.80 & 8.18 & 5.40 & 9.90 & 5.95 & 7.84 & 3.15 \\
\hline & 10 & 70.0 & " & 21.00 & 13.90 & 26.93 & 12.80 & 8.78 & 5.65 & 10.88 & 6.05 & 8.40 & 3.25 \\
\hline & 11 & 80.0 & $"$ & 22.28 & 14.10 & 28.65 & 13.00 & 9.64 & 5.95 & 11.85 & 6.50 & 9.34 & 3.28 \\
\hline \multirow{12}{*}{3} & 対照 & 0 & A & 3.60 & 3.10 & 3.45 & 3.00 & 1.39 & 1.47 & 1.43 & 1.65 & 0.60 & 0.40 \\
\hline & No. 1 & 0.5 & $\mathrm{~S}$ & 3.75 & 3.70 & 3.83 & 3.40 & 1.46 & 1.45 & 1.46 & 1.60 & 0.68 & 0.50 \\
\hline & 2 & 1.0 & " & 3.60 & 3.30 & 3.75 & 3.20 & 1.43 & 1.50 & 1.61 & 1.55 & 0.71 & 0.40 \\
\hline & 3 & 5.0 & " & 3.75 & 3.38 & 3.60 & 2.68 & 1.28 & 1.25 & 1.43 & 1.45 & 0.71 & 0.46 \\
\hline & 4 & 10.0 & " & 5.10 & 4.30 & 4.65 & 3.40 & 1.43 & 1.45 & 1.54 & 1.43 & 1.13 & 0.90 \\
\hline & 5 & 20.0 & $r$ & 7.43 & 5.30 & 6.83 & 4.60 & 2.40 & 1.47 & 2.18 & 1.55 & 1.73 & 1.07 \\
\hline & 6 & 30.0 & $"$ & 8.78 & 6.50 & 8.93 & 6.50 & 3.23 & 2.20 & 3.34 & 2.20 & 3.11 & 1.30 \\
\hline & 7 & 40.0 & $"$. & 11.55 & 8.00 & 12.63 & 7.10 & 4.61 & 3.20 & 5.10 & 3.40 & 4.39 & 1.70 \\
\hline & 8 & 50.0 & $"$ & 13.43 & 9.40 & 15.45 & 9.00 & 4.99 & 3.60 & 6.00 & 4.10 & 5.06 & 2.30 \\
\hline & 9 & 60.0 & $"$ & 16.95 & 9.77 & 20.10 & 9.24 & 6.11 & 3.99 & 7.05 & 4.36 & 5.66 & 2.57 \\
\hline & 10 & 70.0 & $"$ & 19.28 & 11.20 & 24.60 & 10.60 & 7.65 & 4.45 & 10.05 & 4.80 & 6.68 & 2.95 \\
\hline & 11 & 80.0 & $"$ & 19.78 & 11.50 & 25.55 & 11.30 & 9.28 & 4.80 & 12.08 & 5.60 & 7.48 & 3.45 \\
\hline
\end{tabular}


第 20 図

三塩化醋酸含有尿汸於ける Ti. 值 $\mathrm{mg} \%$

と「ク」漫水洗による影響（術式 (1))
$A=2$ 回水洗脱水「ク」浸 $\mathrm{V}=\mathrm{V}$
$\mathrm{B}=5$ 回水洗脱水「ク」浸
$(\mathrm{I})=$ 原理(1)，(2)=原理(2)

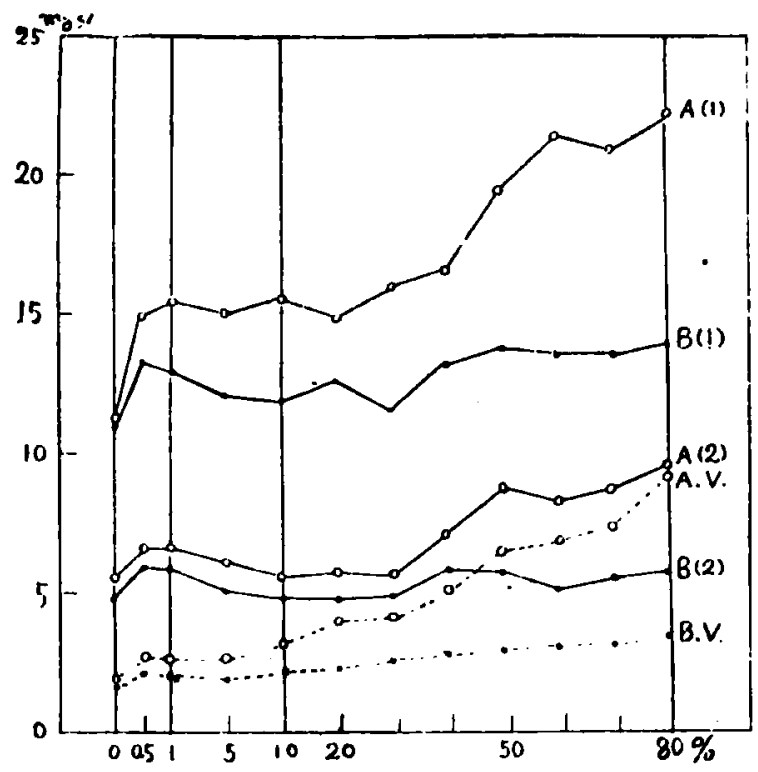

第22図 Farbkurve（術式 (1))，原理 (1))

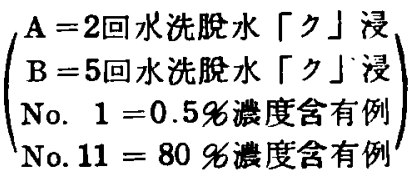

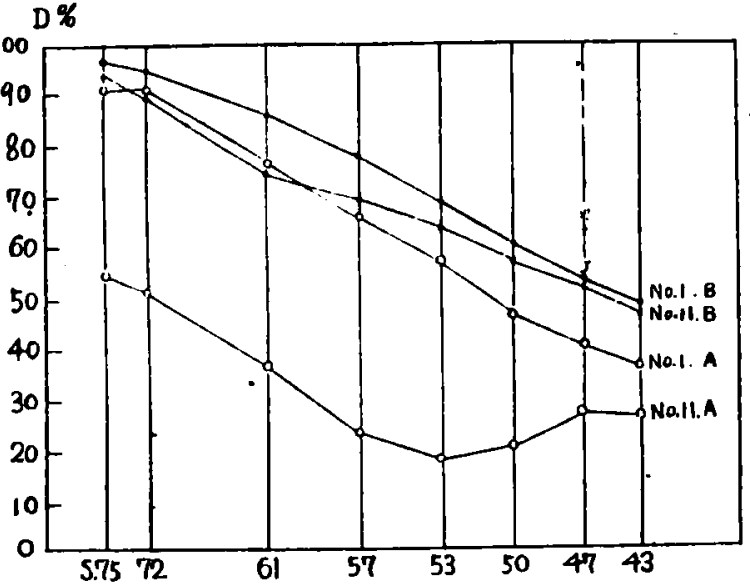

（1） $1 / 20$ 容量の清澄刘使用の場合

被検尿 No. 6 を使用す。清澄滤尿は全最を $52 s$ とし，試験例は各 3 例宛，色素抽出は 2 回，脱水「ク」浸の総量は $8 \mathrm{cc}$ とした. 沈澱 処理は水浴上で 9096 アルコール $20 \mathrm{cc}$ を加え て抽出し，アルコール滤液を乾固した残渣を 水 $10 \mathrm{cc}$ 飞加温溶解し其の $5 \mathrm{cc}$ 飞就いて敍上 の測定をした。
第 21 図

三塩化醋酸含有尿に於ける Ti. 值 $\mathrm{mg}$ \%

と「ク」浸水洗による影響（術式 (3))

$\mathrm{A}=2$ 回水洗脫水「ク」浸 $\mathrm{V}=\mathrm{V}$. 量

$B=5$ 回水洗脫水「ク」浸

(1) =原理(1)，(2)=原理(2)

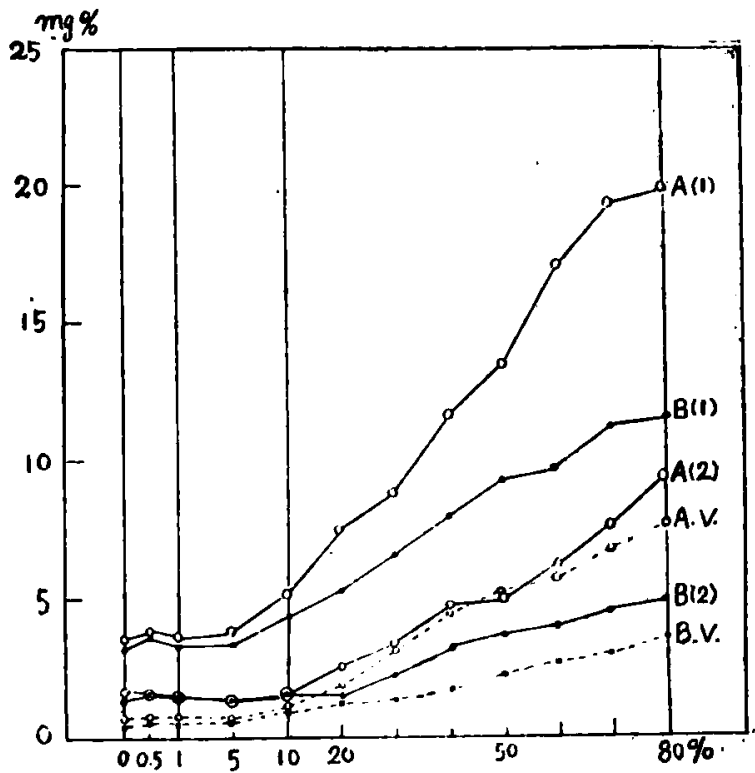

第23図 Farbkurve（術式 (3))，原理 (1))

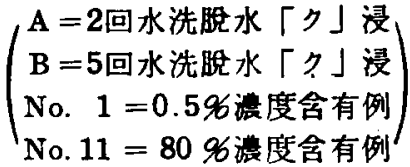

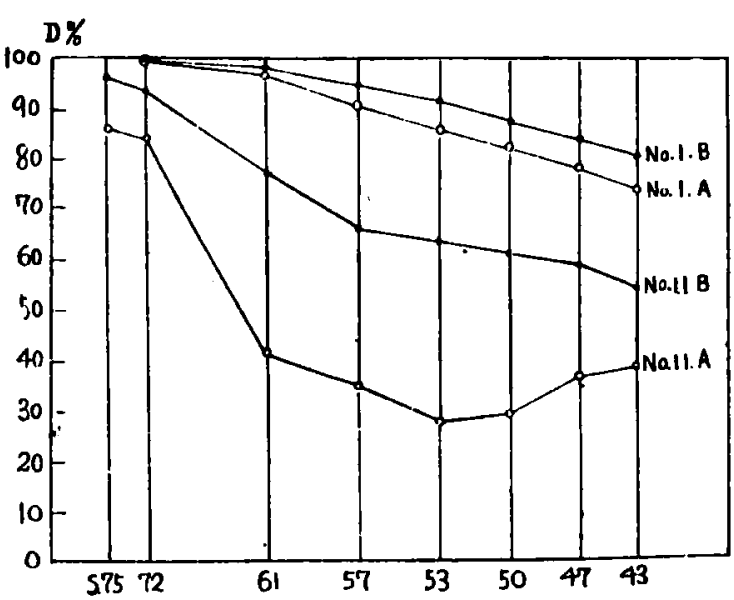

（2） $1 / 10$ 容量の清澄剂使用の場合

・被検尿 No. 7 を使用す。清澄滤尿は全量を $55 \mathrm{cc}$ とし試験例は各 2 例宛，色素抽出は 2 回， 脱水「ク」浸の総量は $6 \mathrm{cc}$ とした. 沈潵処理 は 0.5 名醌酸で反覆抽出したる滤液 $30 \mathrm{cc}$ 中, 其の $5 \mathrm{cc}$ 飞就いて敍上の測定をした。

$$
\text { 実 倹 成 縤 }
$$

成績は第13表，第24図，第25図，第26図の 
如し、第13表から原尿に於ける平均 $\mathrm{Ti}$ 值に 対する醌酸鉛又は塩基性醋酸鉛清澄による $\mathrm{Ti}$ 值低下率を補正平均 Ti 值飞就いて算出する と共に，尿清澄飞伴う Ti 值の平均低下量飞 対する沈澱中の $\mathrm{Ti}$ 值の発見率を原尿 $100 \mathrm{cc}$ 飞換算して算出すると第14表の成緽となる.

（1）清澄剂使用による $\mathrm{Ti}$ 值低下

$1 / 20$ 容量の清澄剤使用では $\mathrm{Ti}$ 值低下率は $-8.0 \sim-10.496$ (原理 (1)) 及び-4.5〜 -6.3 $\%$ (原理 (2))となり，1/10 容量の清澄剂使用 では-31.4〜-36.4\% (原理(1)) 及び-15.4 〜 $-25.0 \%$ （原理 (2)）となる.
$\mathrm{Ti}$ 值低下率は原理 (2)飞比し原理 (1)飞於い て高く又塩基性醌酸鉛清澄飞比し醋酸鉛清澄 そ於いて高率を示す，然して $1 / 10$ 容量の清 澄剂使用による $\mathrm{Ti}$ 值低下率は 1/20 容量の 清澄剂使用時の約 3.5 倍に相当する.

（2）沈洏中のインヂカン発見率

第14表から沈澱中の $\mathrm{Ti}$ 值発見率は, 1/20 容量の清澄剤使用では 42.1 43.2\%（原理 (1)）及び 83.3〜94.1\%（原理 (2)）とな.り, 1/10容量の清澄剂使用では56.2 59.5\%（原 理(1)）及び 59.6〜101.8\%（原理(21）となり, 原理(2)火よる発見率は原理(1)火よる発見梁の

第13 表 尿清澄法による Ti. 值低下と沛激中の Ti. 值発見量測定成績 (( ) 内は補正平均 Ti. 值を示す)

\begin{tabular}{|c|c|c|c|c|c|c|c|c|c|}
\hline \multirow{3}{*}{ 被検尿 } & \multirow{3}{*}{ 尿 清 澄 法 } & \multirow{3}{*}{ 試験番号 } & \multicolumn{2}{|c|}{ 被 } & \multicolumn{2}{|c|}{ 苔尿 } & 沈 & \multicolumn{2}{|c|}{ 汼 } \\
\hline & & & \multicolumn{2}{|c|}{ Ti. 值 $\mathrm{mg} \%$} & \multicolumn{2}{|c|}{ 化均 $\mathrm{Ti}$. 值 $\mathrm{mg} g$} & \multirow[b]{2}{*}{ 沈浇処理 } & \multicolumn{2}{|c|}{ Ti. 俻 mg pro $50 \mathrm{c}$} \\
\hline & & & $\begin{array}{c}\text { 原理 (1) } \\
\text { S. } 47\end{array}$ & $\begin{array}{c}\text { 原理 (2) } \\
\text { S. } 57\end{array}$ & $\begin{array}{c}\text { 原理 (1) } \\
\text { S. } 47\end{array}$ & $\begin{array}{c}\text { 原理 (2) } \\
\text { S. } 57\end{array}$ & & $\begin{array}{c}\text { 原理 (1) } \\
\text { S. } 47\end{array}$ & $\begin{array}{c}\text { 原理 (2) } \\
\text { S. } 57 \\
\end{array}$ \\
\hline \multirow{3}{*}{ 原 尿 } & \multirow{3}{*}{ 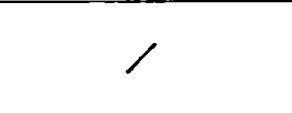 } & No. 1 & 7.05 & 3.83 & \multirow{3}{*}{-7.14} & \multirow{3}{*}{3.81} & \multirow{3}{*}{$\ell$} & \multirow{3}{*}{ I } & \multirow{3}{*}{ ノ } \\
\hline & & 2 & 7.21 & 3.88 & & & & & \\
\hline & & 3 & 7.15 & 3.73 & & & & & \\
\hline \multirow{6}{*}{ 清登尿 } & \multirow{3}{*}{$\begin{array}{c}20 \text { 乐醋酸鉛 } \\
1 / 20 \text { 容㻎 }\end{array}$} & No. 1 & 6.05 & 3.58 & \multirow{3}{*}{$\begin{array}{c}6.15 \\
(6.40)\end{array}$} & \multirow{3}{*}{$\begin{array}{c}3.43 \\
(3.57)\end{array}$} & \multirow{3}{*}{ 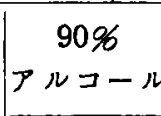 } & \multirow{3}{*}{0.16} & \multirow{3}{*}{0.10} \\
\hline & & & 6.15 & 3.28 & & & & & \\
\hline & & 3 & 6.25 & 3.43 & & & & & \\
\hline & 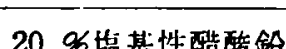 & No. 1 & 6.15 & 3.43 & \multirow{3}{*}{$\begin{array}{c}6.32 \\
(6.57)\end{array}$} & \multirow{3}{*}{$\begin{array}{c}3.50 \\
(3.64)\end{array}$} & \multirow{3}{*}{ " } & \multirow{3}{*}{0.12} & \multirow{3}{*}{0.08} \\
\hline & 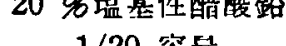 & & 6.25 & 3.48 & & & & & \\
\hline & & 3 & 6.55 & 3.58 & & & & & \\
\hline \multirow{2}{*}{ 原 尿 } & 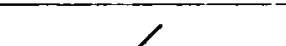 & No. 1 & 6.07 & 3.49 & \multirow{2}{*}{5.97} & \multirow{2}{*}{3.58} & \multirow{2}{*}{$\ell$} & \multirow{2}{*}{$\nearrow$} & \multirow{2}{*}{ I } \\
\hline & & 2 & 5.87 & 3.66 & & & & & \\
\hline & & No. 1 & 3.53 & 2.36 & 3.46 & $2.40_{1}$ & $0.5 \%$ & & \\
\hline 清登屋 & 1/10 容責 & 2 & 3.38 & 2.44 & $(3.80)$ & $(2.64)$ & 醋 酸 & 0.61 & 0.28 \\
\hline 消塏乐 & 2096 㱡巷性醋酸鉊 & No. 1 & 3.75 & 2.74 & 3.72 & 2.72 & $n$ & 0.56 & 0.29 \\
\hline & $1 / 10$ 容量 & 2 & 3.68 & 2.74 & $(4.09)$ & (3.01) & $"$ & 0.50 & 0.29 \\
\hline
\end{tabular}

第24図 Farbkurve（原理(1)）

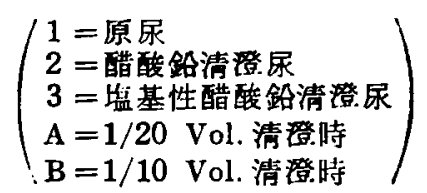

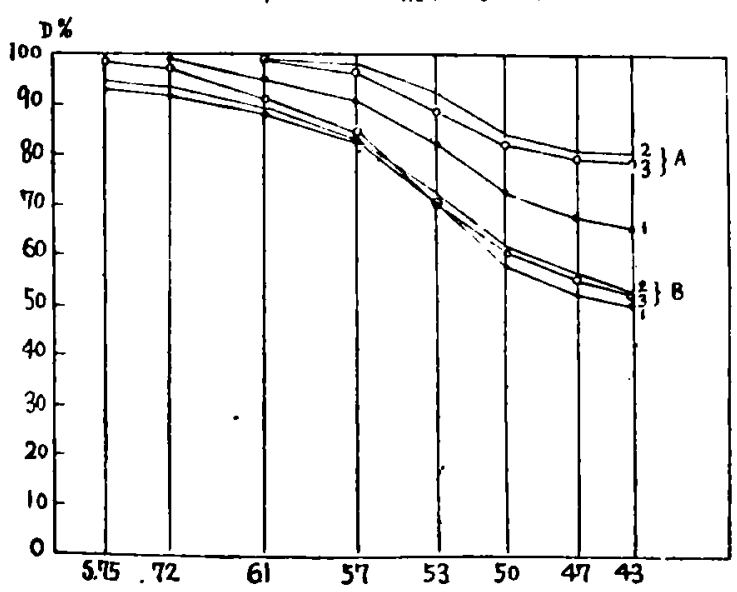

第25図 Farbkurve（原理(2)）

$$
\left(\begin{array}{l}
1=\text { 原尿 } \\
2=\text { 醋酸鉛清澄沓 } \\
3=\text { 塩基性醋酸鉛清澄尿 } \\
\mathrm{A}=1 / 20 \mathrm{Vol} . \text { 清澄時 } \\
\mathrm{B}=1 / 10 \mathrm{Vol} . \text { 清澄時 }
\end{array}\right)
$$

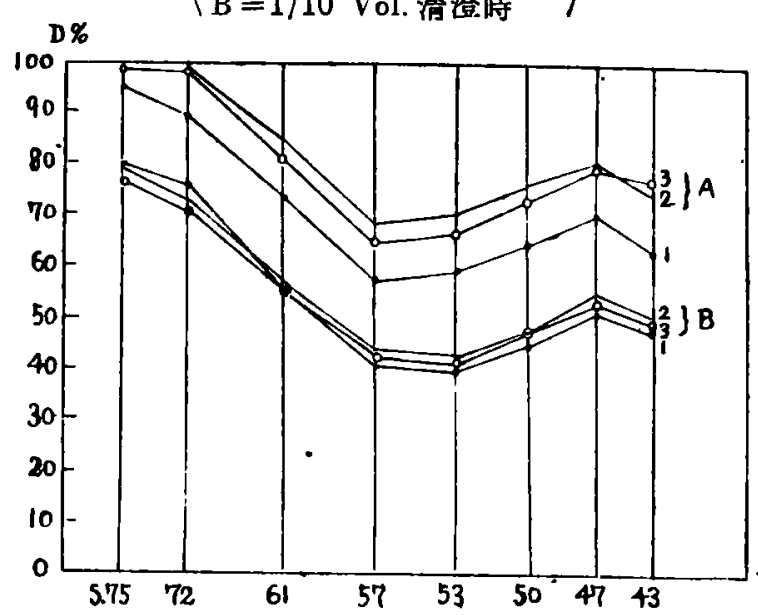


第26図 Farbkurve（沈汼処理時）

A $=1 / 10$ Vol. 清澄沈激の醋酸処理 $\mathrm{B}=1 / 20$ Vol. 清澄沈澱のアルコール 処理 $(1)=$ 原理(1)，(2)=原理(2)

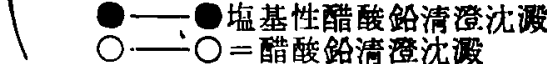

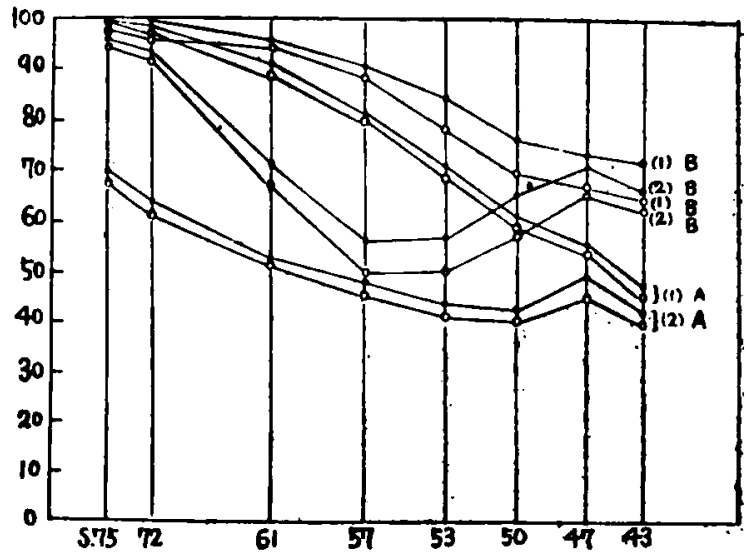

第14表 永清澄剤任よる Ti. 值低下率と 沈泚中の発見率 (\%)

\begin{tabular}{|c|c|c|c|c|c|}
\hline \multirow{2}{*}{\multicolumn{2}{|c|}{ 清 澄 法 }} & \multicolumn{2}{|c|}{$\begin{array}{l}\text { Ti. 值低下率 } \\
(96)\end{array}$} & \multicolumn{2}{|c|}{$\begin{array}{c}\text { 沈䬦中発見率 } \\
(\text { 名 })\end{array}$} \\
\hline & & $\begin{array}{c}\text { 原理 (1) } \\
\text { S. } 47 \\
\end{array}$ & $\begin{array}{l}\text { 原理 (2) } \\
\text { S. } 57\end{array}$ & $\begin{array}{l}\text { 原理 (1) } \\
\text { S. } 47\end{array}$ & $\begin{array}{l}\text { 原理 (2) } \\
\text { S. } 57 \\
\end{array}$ \\
\hline $1 / 20$ & 醋酸鉿 & -10.4 & -6.3 & 43.2 & 83.3 \\
\hline 容量 & \begin{tabular}{|l|} 
塭基性 \\
醋酸鉿
\end{tabular} & -8.0 & -4.5 & 42.1 & 94.1 \\
\hline $1 / 10$ & 醋酸鉿 & -36.4 & -26.0 & 56.2 & 59.6 \\
\hline 容 & 堪基性 & -31.4 & -15.4 & 59.5 & 101.8 \\
\hline
\end{tabular}

平均約 2 倍強に相当す。

(3) Farbkurve

第24図，第25図の如く，原理(1)及び原理(2) による Farblkurve は原尿と清澄尿との間に 大差を認めず，何れも Ti の定型的 Farbkurve に近似するが尚打完全には一致しない。

第 26 図の如く，沈澱処理によりて得た Farbkurve 中，沈澱のアルコール処理による 原理 (2)の Farbkurve が最も Ti の原理 (2)の 定型的 Farbkurve 飞近似し，沈殸の酛酸処 理による Farbkurve は就中原理(2)に於いて 著しく非定型的となつた。

実跧 7. インチカン微量定量法の創案並び 飞正常尿インチカン值飞就いて

1. 私が創案したインヂカン微量定量法. $\mathrm{Ti}$ 值を増強又は低下せしめる諸原因を究 明すべく行いたる全装験を通して得たる成績
を要約すると次の如くである。

(1) 尿に於けるまモール・インドオキンル 縮合は除々飞進行し，竹内氏試薬では 2 時間 で完結する（実験 1 ）。

（2）迮藤氏規準液の力価は理論値に比し著 しく濃厚である（実験 1 ，実験 2 ）.

（3）各種酸化剂中，竹内氏試薬が最優秀で あり 0.5 Obermayer's 試薬は著しく逰色があ る（実験 1 ，実験 3 ，実験 5 ）。

（4）清澄剂使用により尿インヂカンの著し い損失を招来する（実験 6 ）。

（5）三塩化醋酸含有尿に於いては Ti 值は 尿中三塩化酛酸濃度の増減及び「ク」浸の水 洗方法により著しく変動する（実験 4 , 実験 5)

（6）原理 (1) 及び原理 (2)飞よるStufo. 值は 常に不定の誤差を示し原理(2)に於いて低值を 示する，Farbkurve は原理 (2) 飞於いて最も 定型的曲線江近似す（実験 1 ，箺験 3, 実験 4 , $B$, 実験 5 ，実験 6 )。

以上の全尖験成績の要約から尿に於ける Ti の絶対化生量は三種の定量術式中, 術式 (1)に於いて最高值を示す事が判明したのであ るが，原理(1)及び原理 (2)飞よる Stufo. 值が 一致しない事から，既江私が Jolles's 反応の 化学的本態飞就いて実証した如く（第一編 Jolles's 反応の化学的本態江関する実験的研 究参照)「ク」浸中の色素は $\mathrm{Ti}$ のみの単一色 䒺でなく，少なくとも二種以上の色素の混合 せるすのである事を再確認したので，私は Ti 以外の色素性 Indogenid の化生を可及的飞防 止する意四から反応媒質に於けるチモール量 を增量する必要を認めるに至り，チモール量 を10\%チモール・アルコール0.5cck改めた 術式(1)化よりて得られる赤褐色透明脱水「ク」 浸の一定量に原理 (1) 及び原理 (2) を適用する Stufo. 值測定方法を以つて私が創案した尿イ ンチカンの新微量定量法として提案する。本 法によれば尿中インチカン濃度 C (mgg) は 下式によりて算出される.

$\mathrm{C}=\mathrm{E} \times 6.84 \times 0.9 \times$ 脱水「ク」浸容量 $\mathrm{cc}$ （原理 (1). S 47.10mm 液層) 
$\mathrm{C}=\mathrm{E} \times 2.36 \times 0.9 \times$ 脱水「ク」浸容量 $\mathrm{cc}$

（原理 (2). S $57.10 \mathrm{~mm}$ 液層)

但し 0.9 は $\mathrm{Ti}$ 值をインチカン值に換算す る保数であり，原理(2)による定量值を以つて 純粹飞 Ti のみに誘導し得たる尿インデカン 量とし，原理(1)Kよる定量值を以つて Ti を 含む其他の赤褐色の色素性 Indogenid 飞誘導 し得たる㲾インデカンの総量と見なするのと す.

臨床的簡易比色定量法としては，上述の定 量法の原理 (2)の適用に際し遠藤氏規準液を 使用し得る。但し此の場合のインデカン値は, 之に3.08を乗して補正するを要す（実験 2 参 照).

\section{2. 正常尿インヂカン值}

20例の趾康人 24 時間尿飞就いて私の新法に よつて測定した尿インチカン值及び原理 (1), 原理(2)に於ける Farbkurve は第15表及び第 27図の如く，

（1）尿インヂカンの24時間内正常排泄量. 最高 $157.95 \mathrm{mg}$ (原理 (1)) 又は $137.33 \mathrm{mg}$ (原理 (2)),

最低 $42.48 \mathrm{mg}$ (“) 又は $29.83 \mathrm{mg}$ 平均 $98.04 \mathrm{mg}$ ( " ) 又は $77.06 \mathrm{mg}$

（2）尿インヂンの正常濃度.

最高 $22.73 \mathrm{mg} \%$ (原理(1)) 又は $19.69 \mathrm{mg} \%$ (原理 (2)),

最低 $2.52 \mathrm{mg} \%(")$ 又は $1.76 \mathrm{mg} \%$

平均 $9.25 \mathrm{mg} \%(" ）$ 又は $7.45 \mathrm{mg} \%$

(3) 原理 (1) と原理 (2) と於ける定量值誤差. 原理(2)飞於いて +2.2\% -43.0\%で平均 -21.66\%を示した。

(4) Farbkurve

数例の健康人では原理(1)及び原理(2)に於け る Farbkurve か Ti の定型的 Farbkurve に一致し，両者の定量䛧が一致した。
第15表 正常尿インヂカン值測定成績

24時間尿飞於ける正常インヂン值

\begin{tabular}{|c|c|c|c|c|c|c|c|}
\hline \multirow{2}{*}{$\begin{array}{l}\text { 試 } \\
\text { 験 } \\
\text { 例 }\end{array}$} & \multirow{2}{*}{ 别 } & \multirow{2}{*}{$\begin{array}{l}\text { 人 } \\
\text { 名 }\end{array}$} & \multicolumn{2}{|c|}{ 原理 (1), S. 47} & \multicolumn{2}{|c|}{ 原理 (2), S. 57} & \multirow{2}{*}{ 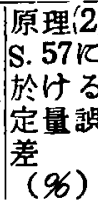 } \\
\hline & & & $\left(\begin{array}{c}\text { 濃度 } \\
(\mathrm{mg} \mathscr{q})\end{array}\right.$ & $\left|\begin{array}{c}\text { 排泄量 } \\
(\mathbf{m g})\end{array}\right|$ & $\mid \begin{array}{c}\text { 灣度 } \\
(\mathrm{mg} \mathscr{6})\end{array}$ & g) & \\
\hline & q & 金谷 & 2.52 & 42.84 & 1.76 & 29.83 & -31 \\
\hline 2 & "1 & 鉿木 & 7.49 & 97.40 & 5.81 & 75.47 & -23 \\
\hline 3 & $"$ & 白井 & 7.36 & 110.36 & 7.43 & 111.38 & $3+1$. \\
\hline 4 & $" 1$ & 但馬 & 2.52 & 47.12 & 1.96 & 36.61 & -20 \\
\hline 5 & $"$ & 阿部 & 22.73 & 136.35 & 19.69 & 118.13 & -13 \\
\hline 6 & $\delta$ & 武藤 & 8.10 & 137.70 & 7.43 & 126.23 & -8. \\
\hline 7 & $"$ & 前田 & 5.40 & 75.60 & 3.95 & 55.29 & -27 \\
\hline 8 & 우 & 角谷 & 4.73 & .88 & 3.51 & 52.65 & -25 \\
\hline 9 & $"$ & 17 & .74 & 64 & 3.58 & 52.85 & +2.2 \\
\hline 10 & $"$ & 久米川 & 14.40 & 57.60 & 13.44 & 53.78 & -7 \\
\hline 1 & $\pi$ & k & 10.13 & 25 & 7.68 & 76.78 & -24 \\
\hline 12 & $"$ & 福島 & 22.02 & 14 & 17.64 & 84 & -21 . \\
\hline 13 & $"$ & 北沢 & 13.23 & 30 & 10.19 & 93 & -23 . \\
\hline & $\pi$ & 細野 & 8.55 & 10 & 5.93 & 47.48 & -31 \\
\hline 15 & $"$ & 木本 & 13.64 & 98 & 11.54 & 126.97 & -15 \\
\hline 16 & $\hat{\delta}$ & 村山 & 12.15 & 157.95 & 10.56 & 137.33 & -13 \\
\hline 1 & $" 1$ & 副田 & 5.74 & 72.29 & 3.65 & 45.93 & -37 \\
\hline 1 & 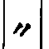 & 進東 & 5.54 & 88.00 & 3.75 & 59.57 & -32 \\
\hline 1 & " & $"$ & 5.63 & 125.49 & 3.29 & 68.87 & -41 \\
\hline 2 & 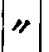 & 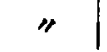 & 6.95 & 102.50 & 3.88 & 58.20 & -43 \\
\hline & & & & & & & \\
\hline
\end{tabular}

第27図 Farbkurve (1) =原理(1)，(2)=原理(2)

No. は試験例番号を示す

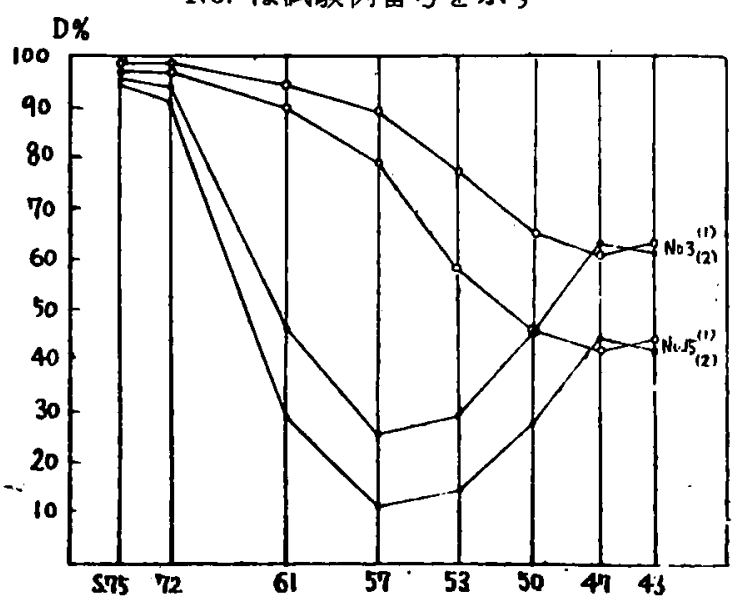

第五章 総括並びに考按

以上の奏験成䋶を総括し，尿インチカン定 量上の諸問題, 就中不確弮なる定量値を得る に至る諸原因に就いて考按するに， 
1. 定量值に及ばす反応特間の影響及び三 種定量術式の評価飞就いて

反応時間の延長飞伴 $5 \mathrm{Ti}$ 值上昇曲線（第 7 図）が示す如く，尿に於ける Thymolindoxyl 縮合反応は術式(1)では比較的速かに， 術式(2)では不規則飞又術式(3)では最も緩慢に 進行し，原理を同じくするStufo. 值は各術式 とも夫々 2 時間值が最大值を示した，然して 三種術式中, 術式(1)の 2 時間値が全成績中の 最高值を示し，然も 2 時間值と 1 時間値との 誤差が最も僅少で 4 \%内外である事から，尿 飞於ける Thymol-indoxyl 縮合は術式 (1) K よれば少なくとも反応時間 2 時間で完結せし め得るるのと推定され，従つて尿インヂカン 定量術式として術式(1)が最優秀である事が笑 証される。

反応時間の短縮に伴 5 Stufo. 值低下の原因 そ関して注目すへきき成績は，術式の如何を問 わず反応時間の短縮に伴い益々濃厚飞出現し 且つ水洗によつて消腿しない脱水「ク」浸の 青色乃至紫色色調の本態である（第 4 表）. Jolles ${ }^{15)}$ は Jolles's 反态化於いては反応時間 を短縮すると青監が化生される点を指摘し Jolles 氏法では反応時間を 2 時間飞延長して いる。私す又 Jolles's 反态及び Jolles ・竹内・ 反応飞準拠して垁施した $\mathrm{Ti}$ の製出控験及び インドオキンル酸からする Ti の合成契験に 於いて Ti の他飞青監が同時に「ク」浸中に 抽出されて居る事実を確認したのであり，敍 上の青色乃至紫色色調の本態は「ク」浸中に 抽出された青監と認定される，即ち反応時間 の短縮飞伴了Stufo. 值低下の原因は算に Thymol-indoxyl 縮合が未完結であるのみな らす，青監の化生を促進する結果侄基因する 事が判明する．然して適量の青監が Ti と同 時飞混在する事は，却つて脱水「ク」浸の赤 褐色色調を増強する結果となり原理(1)による 比色值増強の主因となり，過量の青藍の混在 は遂に原理(1)による比色を不能に陥らしめる 結果となつた（第 4 表）。

反応時間を 2 時間とせる Jolles 氏法活)は Jolles's 反忘を採用せる諸家インデカン定量
法の基本術式となり一般に其の確実性が高く 評価されて居る所であるが, Schlierbach ${ }^{30}$ )は 三塩化醋酸含有尿では Jolles's 反応は反応時 間 30 分で既に不全酸化を防止し得るとし又 Zacherl ${ }^{27)}$ ，竹内 ${ }^{40)}$ は Jolles's 反㤁がインヂ カン定量原理として著しい遜色のある事を指 摘している，此等の諸家業績をJolles 氏法 飞準拠せる術式(3)の Stufo. 值飞就いて倹討す ると, 術式(3)つ 2 時間值が術式(1)の 2 時間值 飞比し実に-59.3〜-58.7\%（第 5 表 No. 1), $-55.7 \sim-50.9$ \% (第 8 表) 及び $-62.6 \sim$ $-70.7 \%$ （第 12 表，尿中三塩化醋酸濃 度 10 \%時）飞達する著しい $\mathrm{Ti}$ 值低下率を認める 私の成績は Jolles's 反応では反応時間を 2 時 間に延長するる尚切尿インデカンの 1/2 1/3.5 量を定量し得ると過ぎない事を実証し たものと云うぺ，従つて Jolles's 反応を态 用せる諸家の尿インチカン定量法(5)16)17)18222) 23)30311) 亿は基本的に著しい定量值低下を招来 せしめる要因が存在する事が指摘される．然 して術式(3)火よる著しい $\mathrm{Ti}$ 值低下の主因は 術式(3)と術式(1)の基本的相違点が酸化剂にあ る事から術式 (3)の Obermayer s $\mathrm{s}$ 試薬が術式 (1)の竹内氏試薬飞比し Thymol-indoxyl 縮合 郕として著しい逊色があり $0.5 \%$ Obermayer's 試薬では反応時間を 2 時間飞延長するる尿沉 於ける Thymol-indoxyl 縮合は完結するに 至らない点炡存在するるのと認められる。

Jolles・竹内・反忍を採用せる遠藤氏法で は反応時間を2〜3分間で完結せしめているが 遠藤氏法の碓俸性を同氏法飞準拋せる術式(2) の Stufo. 值飞就いて検討するに，術式(2)の 2 時間值忏術式 (1)の 2 時間值飞比し - 16.4 $-19.5 \%$ (第 5 表 No. 1) の Ti 值低下を認め るのみならず，反态時間の延長飞伴う $\mathrm{Ti}$ 值 上昇曲線は著しく不規則であり且つ同一試験 例 2 例間の誤差 も $\pm 10 \%$ 亿及ぶ等, 術式(2) 仕 術式(1)《比し可成りの遜色が認められる. 然 して其の原因は術式(2)と術式(1)との基本的相 違点であるクロ、フォルムの注加順序に求む ベく，即ちクロ、フォルムを発烟塩酸注加前 と入れる術式(2)刀順序によれば，クロ、フォ 
ルム易溶性のチモールの相当量が既にクロ、 フォルム層に移行し, 発烟塩酸注加後に初め て開始される Thymol-indoxyl 維合に際し て反応媒質て於けるデモール翼が不足する結 果となり却つてインドオキンル相互の縮合即 ち青藍の化生が助成せられ Ti の化生量は相 対的飞减少する覀条件を促進するるのと推定 される. Jolles's 反応飞於いて反出媒質に於 けるチモール量の不足が青監化生の原因とな る事は既に Benzinger(1)の指摘する所であり， 術式(2)では反忘時間を延長するも尚拓脱水 「ク」浸に青藍の混在を容易ならしめた成績 る以上の推定によつて解明される。

2. 遠藤氏規準液の評価飞就いて

遠藤氏規华液の Farblkurve は S 53 で，Ti 「ク」溶液の原理(2)の Farbkurveは S 57 で最 るよく吸光するが両者の Farbkurve は極め て近似する (第 10 図), 従つて其の色調に於 いては遠藤氏規準液の優秀性が立証される。

但し Ti「ク」溶液の原理 (2) 飞於ける比吸光 係数は，Ti 濃度として算出した遠藤氏規準 液の比吸光係数の約3.6〜 3.7 倍 (S 53) 乃至 3.0 3.2倍（S 57）飞相当し(実験 2 の成績), 従つて遠藤氏規準液の力価は理論值に比し䄪 3.0 3.6倍濃厚なる事を示す。比の事は術式 の如何を問わず原理(2)の 2 時間值飞於いて比 色値が Stufo. 值の約 1/3.3 1/3.5 飞過ぎな い著しい定星值低下の原因（第 5 表 No. 3) を 解明するに充分である，元来，遠藤氏21によ る遠藤氏規準液の力価決定方法は Ti の純料 結晶に就いて赛施したのではなく，竹内氏 法 ${ }^{20}$ 亿よつて測定される尿インヂカン值を基 準として決定されたすのであり，此の点が遠 藤氏規蕉液の力価を甚だしく濃厚なるのにし た主因と認められるのであり，以上の考按か ら竹内氏法では従つて尿インチカンの約 $1 / 3$ 〜1/3.6 量を実測し得るに過ぎない事が闆接 に証明されたるのと称すべきである。

3. 各種酸化剂の評価に就いて

インギカンを Ti 亿誘導して定量せんとす る諸法 15)(6)17)(8)22)23)30)31) 飞於いては専ら Jolles's反心が適用され，従つて酸化剂は必然
的に Obermayer's 試楽が使用され，僅か炕 1 名䧟硫酸カリ 26)及び竹内氏試楽21)が使用され たに止まる。

奏験 3 の成績から定量值の高低，原理(1)と 原理(2)《於ける定睥值誤差の大小及び Farbkurve の相似性の三方面から尿飞於ける Thymol-indoxyl 縮合剂としての各種酸化剂 の優劣を評価するに，竹内氏試薬が最優秀で あり，0.5\% Obermayer's 試楽， 1〜5\%過 硫酸アンモン，4\%クロールカルク、10\%硫 酸銅，196塩素酸カリ及び $3 \%$ 過酸化水素の 順位となる. $2 \%$ 亜硝酸ソータでは原理 (1) 亿 於いて最高値を，原理(2)で第 2 位の高值を定 量し得るる，其の Farbkurveは何れる非 定型的であるのみならず対照例飞於いて 4. nitrosolhymol ${ }^{42)}$ と推定される多量の黄赤色 色素の化生せられるを認める故に亜硝酸ソー 夕は酸化剂として使用に耐えない.5\%塩素酸 カリに於いても原理 (2)の $\mathrm{Ti}$ 值は原理 (1)の Ti 值の 1/6 亿過ぎず，其の Farbkurve は何 れる非定型的であり脱水「ク」浸中の色素の 大部分は $\mathrm{Ti}$ と認め難く, 従つて $5 \%$ 塩素酸 カリる酸化郕として使用に耐えない，竹内氏 試薬による Ti 值に対する其他の酸化剂によ る $\mathrm{Ti}$ 值は何れる著しく低値を示し，第 2 位 の Obermayer's 試楽飞於いて既に約 $1 / 2$, 第 3 位の 1 5\% 過硫酸アンモンで約 $1 / 2.5$, 其他の酸化剤では約 1/3〜1/4 を実測し得る に過ぎない。

4. 醰酸並びに三塩化醋酸含有尿に於ける 定量値変動飞就いて

尿 $\dot{⿱ 亠 乂}$ 於ける醋酸濃度と定量值の関係を検 䇣した業績は文献上見られないが，泉了に於 けるJolles's 反心增強及び其の增強本態に 就いては，尿インヂカン定量上の重要問題と して既に Snapper ${ }^{43)}$, 石神 ${ }^{22)}$, Sharlit ${ }^{26)}$ 等 の指摘する所であるが，其の見解には著しい 相暹が認められる。即ち Snapper は尿 3 に於 ける Jolles's 反岕の増強本態を新赤色色菜の 形成によるものと仮想すると共に，JollesRosenberg 氏法 ${ }^{44)}$ の増強度は1.6 倍なりと報 告す。石神22)はインヂカン水溶液に於ける 
Jolles's 反応の増強度は, 被検液中の三塩化 醋酸濃度により異なり，三塩化醋酸濃度 2.8 96以上では約 3 倍にして岀の增強本態はチモ 一ルと三塭化醋酸との間に生ずる油状物質に よると報告し，画氏とる定量值は增強度で補 正する必要性を指摘せり，又 Sharlit ${ }^{26)}$ は Sharlit's 反応は Jolles's 反応の 2.5 倍の増強 度を有するとし，其の增强本態を Aethyltrichloroacetate なる有機溶媒が化生される事に 帰せんとしている。

実験 4 の成績は，Ti 值が被検尿中の醋酸 又は三塩化醋酸濃度により著明に変動する事 実を示した点で注目に価いする，即ち尿 は $\mathrm{Ti}$ 值は尿中醋酸濃度が $0.5 \%$ 前後の弱酸 性尿で既に最高值を示し，尿中醌酸の過剩は 却つて Ti 值の低下を招来することを実証し ている。此れは主として Ti が醋酸に易溶性 であるため, 醋酸の過剩は反忘母液からの Ti 抽出を益々困難にする事に基因するものと推 定される。

反之, 尿 3 では Ti 值は尿中三塩化醋酸濃度 の増加に伴い増大し，尿中三塩化醋酸濃度が 1096前後の強酸性尿で最高值を示し尿中三塩 化醋酸の過剩は Ti 值低下の原因とならない のみならず原理(1)反よる比色を遂に不可能な らしめる結果となる。此れは Ti が三塩化醋 酸飞易溶性であるにも不拘，尿3では反応母 液からの Ti の抽出で容易であり且つ尿中三 塩化醋酸濃度の増加飞伴 $5 \mathrm{v}$ 量の増量により, 脱水「ク」浸の赤褐色色調が暗赤褐色乃至暗 紫赤色飞增强せられる結果飞基因する. 被検 尿を同しくなる㲾 1 と尿 3 の最高 Stufo. 值を比 較するに，原理(1)Kよる $\mathrm{Ti}$ 值は尿 3 では尿 の約1.3倍（第16困）又は約 1.7 倍（第19図） で平均 1.5 倍の増強を示すが，原理(2)飞よる $\mathrm{Ti}$ 值は尿 3 では尿、に比し約 10 960增強を示 すと過ぎない(第19図). 即ち原理 (2)の定量 值を Ti の絶対值と認定する時は尿 3 K於け る原理(1)の定量值は明らかにV量によりて增 强された定量値と見るべきである。然して 尿3の原理(2)の最高 $\mathrm{Ti}$ 值飞対する原理(1)の 定量值增強度は約 2.7 倍 (第19図) 又は約2.3 倍（第 10 表，術式 (1)，No. 1，B浸）で平均
約2.5 倍となり, Sharlit が指摘した Sharlit's

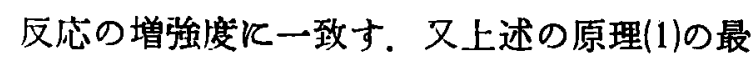
高 Ti 值慻られる尿 3 の尿に対する平均 增强悽 1.5 倍は Snapper が指摘せる JollesRosenberg 氏法の增強度火概ね一致す，以上 の成績から原理 (1)飞よる定量值は尿3では明 らかに增強度で補正する必要が認められる。

然るに注目すべきは実験 5 の成績が示す如 く，尿3に於ける Ti 值は術式，原理及び尿 中三塩化醋酸濃度を異にすることにより著し い変動を示すのみならず「ク」浸の水洗方法 そよりて甚だしい相違を招来する事である。 即ち水洗 2 回のA浸では術式, 原理の如何を 問わず $\mathrm{Ti}$ 值は尿中三塩化醋酸濃度の増加飞 伴 5 脱水「ク」浸中の $\mathrm{V}$ 量の増量と共に増大 し遂泳中三塩化醋酸濃度 80 \% 6 亿於いて最 高值を示す事であり，其の定量值增強度は尿 中三塩化醋酸濃度の増加飞伴いて増大し，原 理 (2) 飞於ける定量值堌强度は原理 (1) 飞比し て高く, 又術式(3)即ち Jolles's 反応飞於ける 定量值增強度は術式(1)反比し異常の高济を示 す.

A浸のV量（紫色色調濃度）は爾後 3 回の 水洗により徐々に消裉し B 浸では V 量は術式 の如何を問わず尿中三塩化醋酸濃度10\%以下 の試験例では脱水「ク」浸中に明暸なる柴色 色調としては認め難い存在となるも尿中三塩 化醋酸の高濃度の試験例では尚お之れを認め 得る。

実験 5 の成績（第10表）が示す如く，Ti值 の最高值は A 浸飞於ける術式 (1), 原理 (1) 飞 よる $28.65 \mathrm{mg} \%$ ( S 50)又は $22.28 \mathrm{mg} \%$ ( S 57) で, 最低值は B浸に於ける術式(3)，原理(2)飞 よる1.25mg\%（S 57）又は $1.43 \mathrm{mg} \%$ (S 53) であり両者間に見られる定量值の警異的な誤 差は実に㲾3に於ける三塩化醋酸濃度, 術式, 原理及び「ク」浸の水洗回数を夫々翼にする 諸要因炕よつて招来されたものである．然し て第10表の成績中, 最る正確なる $\mathrm{Ti}$ 值とし てはV量による定量值增強が考虑されない条 一件下の最高 Ti 值即ち術式(1), 原理(2), 尿中 三塩化醋酸裖度 $0.5 \%$ \%於けるB浸に就いて 
測定し得たる 5.95mg $\%$ （S 57）と認定され る.

術式(3)即ち Jolles's 反芯のインヂカン定算 原理としての迩色は尿子に方:いても指摘され るのであり㽷中三塩化醋酸漰废10\%に於ける $\mathrm{Ti}$ 值は街式 (3) では術式 (1)の約 1/3〜1/3.5 に過ぎない（第 10 表），以上の成績は単に尿3 のみならず22)23)30)，三塩化醋酸除蛋白捬液に Jolles's 反応を適用している諸家血液インチ

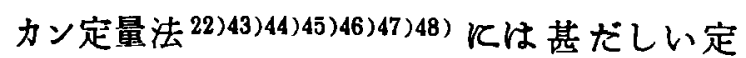
量値の低下を招来する重大欠陥が存在してい る事を示すと共汇, 被検液中の三塩化醋酸濃 度を増加するか又は「ク」浸の水洗回数を省 略する手段によつて定量值を不当に増強せし め得る事実を示している。

次飞尿 3 K於ける Ti 值増强の主因と認めら れる $\mathrm{v}$ 量の本態飞就いて考按するに，尿中三 塩化醌酸濃度の增加飞伴 $5 \mathrm{~V}$ 量の堌量曲線 （第16図，第20図，第21図）と「ク」浸層の 溶量及び分離洗液量の増量曲線（第18图）の 三者が相似した曲線を示す成績から，A浸即 ち水洗不充分なる「ク」浸の V 量は，一部に 於いて脱水「ク」浸中飞含有される微量の塭 酸及び三塩化醋酸飞よる $\mathrm{Ti}$ の呈色反応（青 紫色及び紫色）が考㦄される．但し Ti の対 塩酸又は対三塩化醋酸呈色飞よるTi「ク」溶 淥の紫色着色は水洸により直に消失する（第 一編，Ti の理化学的性状参照）飞対し，A 浸の紫色色調は水洗により徐々飞消螁し且つ 紫色色調が残存している安浸に於いてはクロ ロフォルム以外の特有なるエステル様芳香が 感得され，斯る芳香はV 量の增量に伴いて強 く然尿、では尿中醋酸澎度 8096 の試験例に 於いてる認められない等の諸事实から推察す るに，尿 3 のB浸の V 量の本態は敘上のエス テ儿棣芳香性物質の形成飞基く $\mathrm{Ti}$ の呈色反 応（紫色）飞よるものと推定され，本物質は Sharlit's 反応の増強本態として Sharlit が指 摘した Aethyltrichloroacetate なる有機溶媒 と同類のもの小如く考えられる。

以上の成績が明示する如く，尿 3 亿於ける $\mathrm{Ti}$ 値の增強度は沓中三塩化醋酸濃度, 術式,
原理及び「ク」浸水流方法により著しく不定 で，正碓なる補牙:值を求め㖉く，正破なるTi 值は尿に汸いて測它おへきである。但し尿 を使用与る欠点は，尿了に比し Ti の抽出に 遜色があり，原 では第2 回 $\mathrm{Ti}$ 抽出量は第 1 回抽出量の約10\%であると刘し疛 20\%を示す点である（第 7 表，0.5〜10\%間）.

5. 尿清澄剂々よる定量値低下飞就いて

Bleiessigfällung Kよる尿インヂカン損笑 飞関し Ellinger ${ }^{7)}$, Porcher-Hervieux ${ }^{49}$, Schlierbach ${ }^{30)}$ は之れを否定するすBöhmGrüner ${ }^{29)}$ は -38〜ー58\%の警くべき損失率 を報告す。 又 Eucker ${ }^{31) は-15 〜-40 ~ は ~ の ~}$ 損失率を報告すると共飞損失量相当量のイン チカンを沈港中に発見している。

以上の諸家業績を実験 6 の成績から検討す るに, 醌酸鉛及び塩基性醋酸鉛により $\mathrm{Ti}$ 值 は明らかに低下するが， Ti 值低下率は清澄 剂の種類及び容量によりて異なり，同容量の 清澄では醁酸鉛による低下率が高率を示し， 1/10 容量の清澄では $\mathrm{Ti}$ 值低下率は $1 / 20$ 容 量清澄時の約3.5倍飞相当し, 原理 (1) 飞於け る $\mathrm{Ti}$ 值低下率は原理(2)飞比し高率を示す。

沈澱中のインチカン発見率は原理(2)飞於い て高率を示す。夹証し得たる1/10容量清澄時 の $\mathrm{Ti}$ 值低下率 $(-15 \sim-36.4 \%$ ) 並びに 原理(2)炕よる発見率 (84.7\%) は概ね Eucker の報告に一致する成績を得た。原理(1)又は原 理 (2)に於ける Farbkurve の定型的曲線との 相似性並びそ原理(1)と原理(2)の $\mathrm{Ti}$ 値間の誤 差の比率飞於いてても原尿と清澄尿の両者間飞 於いて大差なく，清澄剂使用は徒らに尿イン チカンの損失を招き定量值低下の重要原因と なるのみであり，既飞 Böhm-Grüner ${ }^{29)} の$ 指 摘する如く清澄尿を使用する旧来の各種イン チカン定量法の確等性は否定されるべきであ り稀釈尿が使用されるべきである。

沛澱中のインヂン発見率は沈激の処理方 法によりて著しく異なり，90\%アルコールに よる沈澱処理の場合は発見率は極めて良好で， 其の Farbkurve は Ti の定型的曲線に最も近 似する事は注目に価いする。 
6. 原理(1)及び原理(2)飞於ける定量值間の 誤渼沉就いて

Jolles's К心に哺忛る「ク」浸中の色素を 単一なる Ti のみであると主张せる Jolles ${ }^{15)}$ に対し竹内 ${ }^{40}$ は二種以上の有色物質の混成体 ならん事を指摘し，私も又 $\mathrm{Ti}$ の製出䒠験に 份いて Jolles's 反応及び Jolles ・竹内・反応 の呈色物質は Ti のみでなく青監及び本態不 明の非結晶性褐色色素の混合体である事を奏 証したのであるが，奏験 1，実験 3，実験 4, 奏験 5 及び実験 6 の成績を通してて同一脱水 「ク」浸に於ける Stufo. 值（2時間值）が原 理 (1)の $\mathrm{Ti}$ 值飞対し原理 (2)の Ti 值に於い て不定の低下事を示す事が常見された． 就中， 三塩化醋酸含有尿に於ける原理(2)の Ti 值低 下率は最も高率 $(2.5: 1)$ を示し，其の主因 がV量の増量に伴5原理(1)の定量值增強にあ る事は既述の如くである．然るに弱醋酸酸性 稀釈尿汸於いて子術式，酸化剂及び清澄法の 如何を問わず原理(2)の $\mathrm{Ti}$ 值低下率は可成り の高率 (-27〜-45\%) を示した. 以上の 成績は即ち, 術式, 酸化剂及び尿清澄法の如 何を問わず，弱醋酸性㲾に於ける脱水「ク」 浸中の色素は単一なる Ti のみでなく，少な くとも二種以上の色素の混合体である事を意 味し, 従つて原理(1)又は原理(2)Kよる $\mathrm{Ti}$ 值 の何れを以つて 'Ti の絶対値と認めるかがイ ンチカン定量上の重要問題となる．然して脱 水「ク」浸の原理 (1) 及び原理 (2) 飞於ける Farbkurve を通覧するに，原理 (2)の Farbkurve が定型的曲線に最も近似乙然も原理 (2) に於ける脱水「ク」浸の青柴色は $\mathrm{Ti}$ の特有 の対塩酸呈色反态である理由から，原理(2)の $\mathrm{Ti}$ 值を以つて Ti の絶対值と認める事が適当 且つ合理的であると考劣られる。但し赤褐色 の脱水「ク」浸中に抽出された原理(2)の定量 値低下率相当量の $\mathrm{Ti}$ 以外の色素の本態が尿 インヂンル由来する色素性の Indogenid で あると仮定すれば，原理(1)による $\mathrm{Ti}$ 值は尿 インヂカンの絶対量を測定する上に重要意義 を有するるのと称されるべきである，曹つて 尿インヂカンを青監唀導して䇥星せんとす
る場合，青藍と同時に「ク」浸中に抽出され る褐色及び赤色色素をインデカンに由来する Indogenid と諗めるか否かがインヂカン定量 上の重要問題として Bouma ${ }^{50) 51)}$ Maillard $^{10)}$ Ellinger ${ }^{7)}$, Obermayer ${ }^{52)}$ の間で論争された所 であるが，尿インヂカンを Ti 唀導して定 量せる私の実験成絈からす赤褐色の脱水「ク」 浸中飞同時飞抽出され（從つて其の色調は赤 色乃至蝎色と推定さる）る敍上の Ti 以外の 色素を Indogenid と認めるか否かは原理(2)飞 よる Ti 值低下率が可成の高率を示す点飞於 いて特に重要視されねばならない. 然して原 理(1)に於ける Farbkurve が常にS 43 で最も 良く吸光し然 Ti の定型的 Farbkurve Ti の製出実験飞於ける非結昆性蝎色色素の Farbkurve の中間型を示す点から敍上の脱水 「ク」浸中に存在する Ti 以外の赤褐色類似の 色素の本態は私の製出実験に於ける非結晶性 褐色色素と同一又は同類のすのである事が推

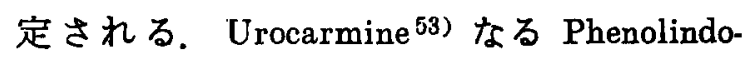
genid はクロ、フォルム不溶解性なる事が報 告されているが, Jolles's 反応の Thymol K 代るに o・Xylenol 及び P・Xylenol を使用 するす Jolles's 反忍に於ける.如き着色「ク」 浸を得る事 ${ }^{39)}$ 及び Jolles・竹内・反応の Thymol K液状石炭酸を代用し得る点 ${ }^{40)}$, 並 びに強力なる酸化用では常尿成分である Kreatinin が Urocarmine 反応を与える報告53) は 5 \%塩素酸カリを酸化剂とせる場合に Ti 以外の赤裮色色素が可成り多量に「ク」浸中 飞抽出される私の成績（実験 3) と共飞, 敍 上の「ク」浸中に Ti 之同時飞抽出されてい る本態不明の赤褐色色素の化学的本態を推定 する上に注目すべき成績であり，私は之れを 常尿成分として存在する特殊の Phenul 誘導 体と尿インヂカンに来ずるインドオキンル の縮合によりて生じたクロ、フォルム溶解性 の Indogenid ならんと推定するすのであり， 従つて原理(2)火よる $\mathrm{Ti}$ 值を以つて Ti の絶 対化生量と認めると共に，原理(1)飞よる定量 值を以つて尿インヂカンに由来する Ti を含 む凡ての赤褐色の Indogenid の総化生量を $\mathrm{Ti}$ 
值として表現せるすのと認めんとするすので ある。

7. 正常尿インヂカン值より見たる各媑イ ンチカン定量法の評価に就いて。

実験 7 の成績の如く，私の新法によれば疗 インデカンの正常一日排泄星は 43〜158 mg （原理(1)）又は $30 〜 137 \mathrm{mg}$ (原理(21) となり， 少数例では原理(1)及び原理(2)飞於ける Farbkurve が夫々 Ti の定型的 Farbkurve K一致 し両者間の定量值が殆ど一致する成績を得た。 就中，私が実測し得たる正常尿インチカン值 は従来の定説（最高 $40 \mathrm{mg}$ ）を遙汃超過す る結果となり，原理(1)による定量值は文献上 最高值を報告せる Sharlit 26 ) の成樍飞，又原 理(2)《よる定量値は Böhm-Grüner 29) の成績 に殆んど一致した。尿インチカンの定量原理 山 Jaffé 炕よる最初の定量法発見以来, 何れ る原則的にインチカンを色素性の Indogenid 飞誘導して定量せんとするるのであり， Indigo (Diindogenid) 1/2)3/5)7/8)9/13/20/27), Indigorot (Isatinindogenid) ${ }^{6) 10) 11}$, Thymolindogenid 15)16)17)(8)21)22)23)26)30), Ninhydrinindo. genid $^{25)}$, Acenaphthenchinonindogenid ${ }^{14)}$ 及び Hexylresorcinolindogenid ${ }^{28) 29) 31)}$ 飞誘導せんと する方法が創案されている.此等の Indogenid の内，実際飞尿からの製出が行なわれ其の化 学的本態が確認されているすのは Indigo ${ }^{54)}$ 及び Indigorot ${ }^{55)}$ の両者に過ぎないのである が，其他の Indogenid 飞誘導している定量法 飞於いて子其の呈色物質が恰も尿インヂカン に由来する単一なる Indogenid であるかの如 き仮定の下に定量が笑施されて居り，斯る事 実は新微量定量法として其の優秀性が注目さ れている Sharlit 氏法, Schlierbach 氏法, Böhm-Grüner 氏法及び Eucker 氏法の本質的 な欠陥として指摘されねばならない。

私が創案した新法の特色は Jolles's 反忍の 化学反応式を尿江於いて確認せる亭験根拠並 びに定量値低下又は增強の諸要因を系統的に 検索せる一連の実駼成績に基いて創案したる のであり其の確”失性を強振するに足り，就中， 格水「ク」浸中の色素の種類を分別して原理
(2)飞於いて Ti の絶刘俻を選択的飞定量し， 原理(1)に於いて Ti を含む総ての尿インチカ ンに由来する可能性のある赤色乃至褐色の Indogenid の総量をる睍知せんとする点は従 米の定量法には見られない特色を有してい る.

臨床的簡易定量法としては術式(1)，原理(2) により遠藤氏規準液を健用する比色定量法が 推獎されるが，此の場合は其の定量值は 3.1 を乗じて補正するを要す。

私の新法によりて笑測された正常尿インチ カン值から推定するに各種定量法中, 新法に 属するSharlit 氏法 ${ }^{26)}$, Schlierbach 氏法30), Böhm-Grüner 氏法29jの実用性は支持されるべ きむ，此等三法の基本的な欠宿は既述の如く， 其の呈色物質の化学的本態が末だ尿に於いて 確認されていない事である。然して Sharlit 氏法は術式が複雑なるのみならず其の呈色本 態 (紫赤色) は $\mathrm{Ti}$ の理化学的性状（第一編 参照）及び $\mathrm{V}$ 量の本熊に関する既述の成績か ら推定するに，少なくとも $\mathrm{Ti}$ の対水醋酸 (赤朱色)，対塩酸（青紫色）及び対三塩化醋 酸（柴色）の三種の呈色反忘による複雑なる 混色状態にあるるのと推定され，従つて $\mathrm{Ti}$ の濃度測定方法としては良好なるものとは称 し難い.Schlierbarh 氏法法術式は簡単なる も三塩化醋酸含有尿江 Jolles's 反応を応用乙 然る応時間を 30 分間飞短縮している点は, 少なくとも尿中インヂカン総量の $1 / 2$ 以上を Ti 飞誘導する事は困難と推定される（総結 及び考按の 1 及び 4 . 参照). Böhm-Grüner 氏 ・法は術式は簡単なるる，定量原理として採用 せる Rose-Exton's 反応の呈色物質とされて いる Hexylresorcinolindogenid ${ }^{28) 29)} の$ 理化学 的性状は今日未だ不明にして，且つ酸化剂 $\mathrm{CuBr}_{2}$ 飞難色のある事から後来之れを 1\% Obermayer's 試薬飞改変せる Böhm 氏法 ${ }^{32)}$ が発表されるに至つている。

然して旧法飞属するJaffés 反心忍，Obermayer's 辰忘，Jolles's 反忘及び竹内氏反等 を定量原理とする彷来の人多数の定量法に゙よ つて测定し報告された正常インヂカン値は私 
が実証し得た定量值の $1 / 3$ 乃至 $1 / 6$ K過ぎず (第 1 表)，此等の諸法には甚だしい定量值低 下を招来せしめる諸要因が存在し其の実用性 は殆んど否定されるべきすのであると思考さ れるのであり，斯る理由から旧来の定量法に よつて究明されたインヂカンの臨床的意義に 関する広䈖な研究業績は更めて確実性ある定 量法によつて再検討されるべき必要性が痛感 される次第である。

\section{第六章 桔論}

1. Jolles's 反心伈び Jolles ・ 竹内・反忘 を中心に，尿インチカン定量值変動の諸原因 を系統的に究明し，尿インヂカンの絶対量を 略々満足飞測定し得る新微量定量法を創案し た.

2. 新法により健康人24㭙間尿飞就いて得 たる正常インヂカン值は次の如く従来の定説 飞比し警異的高值を示した，但し原理(2)によ る定量値を以つて純料飞 Ti のみに誘導し得 たるインヂカン量と認め, 原理(1)飞よる定量 值を以つて Ti を含む其他の Indogenid 飞誘 導し得たる総インヂカン量とする。

(1) 正常一日排泄量 $\mathrm{mg}$ : 最高 158.0 (原理(1)) 137.0 (原理(2)) 最低 $42.5(" \prime) \sim 29.8("$ " 平均 $98.0(" \prime) \sim 77.0("$ " ")

(2) 正常濃度 $\mathrm{mg} \%$ :

最高 22.7 (原理(1)) 19.7 (原理(2)) 最低 $2.5("$ (") $1.8("$ " ) 平均 $9.3("$ " $) \sim 7.5(" 1 ")$

(3) 原理(1)の定量值に対する原理(2)の定. 量誤差は + 2.2〜 - 43.0 96で平均 一2;.7\%である.

3. 究明し得たるインヂカン値変動の諸原 因は次の如し。

（1）尿に於ける Thymol-indoxyl 縮合 は徐々に進行し， $\mathrm{Ti}$ 值は反心洔間の延 長と共に增大寸るが術式(1)即ち竹内氏試 楽では反忍侍間 2 時間で完結せしめ得る。 （2）反心時間の短縮飞伴 $5 \mathrm{Ti}$ 值低下の 原因は Thymol-indoxyl 縮合が未完絬で
あると同時に青藍の化生が助成せられる とよる。

（3）Jolles's 反応の沓インヂンン定量原 理としての確実性は甚だ不良にして，2 時間值に於いて既に-51〜-71\%6定量 值低下を招来す.其の主因はObermayer's 試薬による不全酸化に基因す。

（4）遠藤氏法に於けるクロ、フォルムの 注加順序は青監の化生を助成し Ti の化 生量を相対的飞减少せしめる結果となり， 2 時間值に於いて既に -2096 の定量値低 下を招来す。

（5）遠藤氏規準液は其の色調飞於いて優 秀なるも，其の力価は理論值の約 3 倍一 3.6 倍飞相当し著しく濃厚である，其の 原因は力価決定飞際し倳藤氏は竹内氏法 によるインチカン值を基準とした事によ る.

（6）尿に於ける Thymol-indoxyl 縮 合 剂として竹内氏試薬は最優秀であり，1 96 塭素酸力リ， $3 \%$ 過酸化水素， 1 ～ $\%$ 過硫酸アンモン，4\%クロールカルク 及び10\%硫酸銅の酸化維合能力は同一条 、件下では竹内氏試楽の $1 / 2$ 以下飞過ぎな い. 亜硝酸ソー夕は 4. Nitrosothymol を 化生せしめるを以つて使用に耐えない。

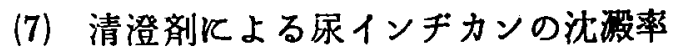
は清澄剂の種類及び容量によりて異なる。 20 \%醌酸鉛又は $20 \%$ 塩基性醌酸鉛の 1/10 容量清澄では夫々 $26.0 \sim 36.4 \%$ 又 は15.4〜31.49 であり； $1 / 20$ 容量清澄 では前者の約 $1 / 3.5$ の沈澱率飞過ぎない 沈汼量の83〜94\%に相当するインチカン は沛耤中に発見される。

（8）被湌尿，術式，酸化剂及び清澄法の 如何を問わす脱水「ク」浸の Farbkurve は大多数に於いて定型的曲線に近似する す完全には一致せず原理 (1)による Ti 值 は原理(2)《よる $\mathrm{Ti}$ 値に比し不定の增強 を示す．其の主因は尿に於けるThy molindoxyl 緶合に際しては青監の化生を防 止するる尚拓 $\mathrm{Ti}$ の他にクロ、フォルム 
容解性の蝎色色素が化生せられるによる。 （9）三塭化醋酸含有尿（以下尿 3) 飞於 ける Ti 值測定に際しては「ク」浸を頻 回水洗するを要す。然らざる時は尿中 三塩化醋酸浱度の増加に伴い紫色色調 （V量）が赤褐色の脱水「ク」浸中に濃 厚飞出現し $\mathrm{Ti}$ 值は家中三塩化酷酸濃度 の増加と洪飞增強せられ，80\%浱度で第 異的高值を示す結果となる。

(10)尿了《於ける Ti 值增強の主因は脱水 「ク」浸中に出現する紫色色調 ( $\mathrm{V}$ 量)で あり其の本態は $\mathrm{Ti}$ の対塩酸及び対三塩 化醋酸呈色反㤁（青紫色及び柴色）によ る以外次，エステル様芳香性物質の化生 による $\mathrm{Ti}$ の呈色反応（紫色）飞基因す るものな如し。

（11）醋酸含有尿（以下尿1）に於ける $\mathrm{Ti}$ 值は尿中醋酸竖度が 0.5 \% 前後の弱酸性 尿で最高值を定量し得る，尿中醋酸の過 剩は却つて反念媒質からの Ti の抽出を 困難ならしめ定量値低下の原因となる。

(12) 尿3 亿於ける Ti 值は尿中三增化醋 酸濃度が10\%前後の強酸性尿で最高值を 定量し得る。尿中三塩化醋酸の過剩は V 量の増量に伴 5脱水「ク」浸の色調増强 により定量值低下の原因とならず却つて 定量值増強の原因となる。

(13) 同一㲾飞於ける最高 $\mathrm{Ti}$ 值は, 原理 (2)では尿1と尿 3 の両者間で大差なきる， 原理(1)では尿3飞狇いては尿、の約 1.5 倍 に増強せられる。

\section{女}

1) Jaffé Arch gesam. phys. Pflügers., 3, S. 448 (1870)

2) Salkowski Virchows Arch. f. path. anat., Bd. 68, S. 407 (1876)

3) Obermayer : Wiener klin. Rdsh., Nr. 34, S. 12 (1898)., Hoppe-Seyler's Z., Bd. 26, S. 427 (1898)

4) Wang Hoppe-Seyler's Z., Bd. 25, S. 406 (1898)
原理(2)の最高 $\mathrm{Ti}$ 值に対する原理(1)の定 量值增强度は尿 1 で平均 1.3 倍, 尿 3 では 平均 2.5 倍である。

(14) 尿 3 亿於ける $\mathrm{Ti}$ 值は增强度で補正 するを要す。但し其の増強度は術式，原 理，尿中三塩化醌酸濃度及び「ク」浸水 洗の方法により不定にして正確なる $\mathrm{Ti}$ 值の測定を期待し難い。

(15) 最高 $\mathrm{Ti}$ 值に於ける $\mathrm{Ti}$ の第 1 回抽 出量飞対する第 2 回抽出量は尿 1 で約 20 \%，㽷3では約 $10 \%$ であり，Ti の抽出は 尿3で良好である.

(16) 原理 (1)の最高 Stufo. 值飞対する比 色值の増强率は尿 1 で約 $5 \%$, 尿 3 で約 10 \%である.

4. 究明し得たるインヂカン定量值変動の 諸原因並び正常尿インヂカン值に関する以 上の結諭から Jolles's 反応を採用せる各種イ ンチカン定量法又は清澄郕を使用する旧来の 大多数のインチカン定量法には著しい定量值 低下の原因が存在するすのと認められる故に， 此等の定量法によつて究明された従来の尿イ ンヂカンの臨床的意義に関する諸業績は確実 なる新法によりて再検討する必要性が強調さ れる。

（本論文の一部要旨は昭和30年度第41回日本消化 器病学会大会に於いて発表した.

本研究は昭和18年 1 月から昭和20年 5 月飞至る間, 満洲医大生化学教室で行つた。誌上発表の機会を得 たるに際して特に当時御愁篤なる御指導を頂いた戸 田茂教授飞深㴬し，御教示並び御校閲を頂いた平

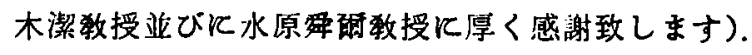

献

5) Wang - Hoppe-Seyler's Z., Bd. 27, S. 135 (1899)

6) Bouma Hoppe-Seyler's Z., Bd. 32, S. 82 (1901)

7) Ellinger Hoppe-Seyler's Z., Bd. 38, S. 178 (1903)

8) Imabuchi Hoppe-Seyler's Z., Bd. 60, S. 502 (1909)

9) Strauss : Dtsch. med. Wochschr., S. 299(1902) 
10) Maillard : Hoppe-Seyler's Z., Bd. 41, S. 437 (1904)

11) Oerum . Hoppe-Seyler's Z., Bd. 45, S. 459 (1905)

12) Autenriet u. Funk : Münch. med. Wochschr., S. 691 (1912)

13) Stanford . Hoppe-Seyler's Z., Bd. 88, S. 47 (1913)

14) Fischer u. Huppmann . Pharm. Ztg., Bd. 76, S. 810 (1931)

15) Jolles : Hoppe-Seyler's Z., Bd. 94, S. 79 (1915)

16) Heilmeyer : medizinische Spectralphotometrie, Monogr. (1936)

17) Baar Die Indicanurie, ihre Bedeutung als Nierenf unk tionsprobe., S. 7, (1922)

18) Eick - Dtsch. Zeit. f. Chirurgie., Bd. 192, S. 330 (1925)

19) Broeckmeyer : Klin. Wochschr., S. 1713 (1932)

20）竹内度次郎：東京医学会雑誌，第37巻，197頁， 大正12年

21）遠藤正治 ·東京医事新誌，No. 2699，11－2440， 昭和5年

22）石神修．医学研究，第14卷，115頁，昭和15年

23）上田春次郎：治療及び処方，78号，789頁，大正 15年

24）公文 適：日本生化学会会報，第8巻，4号，136 頁，昭和8年

25）公文 適 . Hoppe-Seyler's Z., Bd. 231，S. 205 (1935)

26) Sharlit . J. of biol. chem., 99, S. 537 (1931)

27) Zacherl Hoppe-Seyler's Z., Bd. 220, S. 113 (1933)

28) Rose and Exton : J. of biol. chem., 109, S. 76 (1935)

29) Böhm u. Grüner : Klin. Wochschr., S. 1279 (1936)

30) Schlierbach : Dtsch. Arch. f. klin. Med., Bd. 180, S. 439 (1937)

31) Eucker . Zeit. f. ges. exp. Med., 102, S. 589 (1938)
32) Böhm : Biochem. Zeitschr., 290, S. 137 (1937)

33) Wang : Om Indicanurie, christiana., (1900); Cit. 非 ${ }^{38)}$

34）永山正美：成医界月報，No．340，22頁（1910）

35）須藤槵治：医化学的微量测定法，第3版，242頁， 昭和12年

36) Maillard . Bethe., III, S. 279., Cit. 井上38)

37) Olivet - Klin. Wochschr., S. 2439 (1928)

38）井上秀人：朝鮮医学会雑誌，第 23 巻，977 頁, 昭和8年

39) Jolles : Hoppe-seyler's Z., Bd. 87, S. 310 (1913)

40）竹内度次郎 . 東京医学会雑誌, 第31巻, 第19号, 1197頁，大正6年

41) Benzinger - Zeit. f. ges. exp. Med., Bd.83, S. 765 (1932)

42) Schiff : Ber. d. chem. Ges,, 8, 1500 (1875)

43) Snapper u. Bommel : Klin. Wochschr., S. 718 (1922) •

44) Rosenberg Münch. med. Wochschr., S. 117 (1916)

45) Broeckmeyer : Klin. Wochschr., S. 1025 (1933)

46) Böhm u. Grüner . Klin. Wochschr., S. 450 (1936)

47) Schlierbach : Klin. Wochschr., S. 556 (1934)

48）上田春次郎：体液診断学, 第11版，78頁, 昭和 7 年

49) Porcher u. Hervieux : Hoppe-Seyler's Z., Bd. 39, S. 147 (1903)

50) Bouma Hoppe-Seyler's Z., Bd. 27, S. 348 (1899)

51) Bouma - Hoppe-Seyler's Z., Bd. 30, S. 117 (1900)

52) Obermayer : Hoppe-Seyler's Z., Bd. 26, S. 427 (1898)

53) Fearon and Thompson - Bioch. J., Vol. 24, S. 1371 (1930)

54) Baumann u. Tiemann : Ber. d. chem. Ges., 12, 1099 (1879)

55) Rosin . Virchows Arch. f. path. Anat., Bd. 123, S. 519 (1891) 
Department of Internal Medicine, Okayama University Medical School.

(Director : prof. Dr. K. Hiraki)

\section{Experimental Studies on the Quantitative Determination of Indican.}

\section{Part II. Some experimental studies concerning urinal determination of indican.}

\section{By}

\section{Tsutomu Shindo}

1) Laying emphasis on chemical equation of Jolles's reaction, and systematically examining those causes for mismeasurement happened during urinal determination of indican, I was enabled to find out certain new microestimating method for indican, which would prove somewhat satisfactory.

2) As indicated below, the normal value of urinal indican estimated by new method, have acknowledged certain marvelously high values that have far superseded those theories hitherto known. However, I am to recognize the Principle No. (2) i. e., the quantitalive value for indican that was considered to have as its object the colour reaction against the fuming hydrochloric acid, which could purely has enabled to induce it solely into the Thymolindogenide; while, Principle No. (1), i. e., the quantitative value which has for its object the original color of Thymolindogenide, should be recognized as total Indican value, i.e., that was enabled to be induced into every kinds of Indogenide including the very Thymolindogenide :

(1) Normal amount $(\mathrm{mg})$ of excretion within 24 hours.

$$
\begin{aligned}
& \text { highest 158.0 (Principle No. (1)) 137.0 (Principle No. (2)), } \\
& \text { lowest } 42.5 \text { (" " " ) 29.8 (" " } \\
& \text { average } 98.0(" \text { (") } \sim 77.0(" \text { " }) \text {. }
\end{aligned}
$$

\begin{tabular}{|c|c|c|c|c|c|c|c|}
\hline ighe & 22.7 & inciple & No. (1)) & $\sim$ & 19.7 & (Prnciple & No. (2)), \\
\hline & ) 50 & $"$ & $"$ & $\sim$ & 1.8 & $"$ & " \\
\hline & 9.: & " & " & 18 & 7.5 & $"$ & " \\
\hline
\end{tabular}

(2) Normal density $\mathrm{mg} \%$

(3) Misestimation in quantitative value shown by Principle No. (2) to that of Principle No. (1) is estimated as $+2.2 \sim-43.0 \%$; average, $-26.7 \%$.

3) Various stimulants to give rise to mismeasurement on the side of indican at its quantitative determination that have been able to investigate, were as follows.

(1) The condensation between the thymol and indoxyl in the urine increasing at a gradual ratio, and the quantitative value shows a proportional increase as time for reaction lengthens; yet, if the reagent due to Takeuchi (Estimating method (1)) should be used, it may come to an end after two hours' reaction.

(2) The descent in estimation owing to a shortening of reactionary time may roughly be ascribed to the fact that while the condensation between the thymol and indoxyl remains incomplete, the formation of indigo undergoes certain stimulas.

(3) If one might consider the certain of Jolles's reaction as a principle for indican estimation, it would be told as very unsatisfactory ' in fact, even after 2 hours of reaction, already it has been seen to have given rise to so marked a difference as $-51 \sim-719 \%$. Altogether, the chief cause will be pointed out as the incomplete 
oxidation owing to Obermayer's reagent.

(4) Order in adding chloroform according to Endö's method, assists to formulate Indigo, but in the same degree affects to decrease to formulate the Thymolindogenide; so that, in 2 hour's reactionary course, it brings about already $-20 \%$ misestimation.

(5) Endō's standard solution, though excellent in its tint, its titer value amount even to 3 or 3.6 times larger than its theoretical value, being remarkably dense. This may take place, perhaps, when he decided on titer, Mr. Endō employed for standard the indican value estimated by Takeuchi's method.

(6) For an urinal oxidizing agent between the thymol and the indoxyl I might men. tion that of Mr. Takeuchi as best of that kind. The oxidizing agent indicated by $1 \%$ potassium chlorate, 3\% hydrogen peroside, $1 \sim 5 \%$ ammonium persulphate, $4 \%$ chlorinated lime, $10 \%$ copper sulphate, under the same conditions, only cope with $1 / 2$ power proved by Takeuchi's, at most. Whereas, sodium nitrit cannot stand to be used because apt to produce some nitrosothymol.

(7) The precipitation rate due 10 precipitator attributed to urinal indican proves different according to the kinds as well as volume of precipitators. In case $1 / 10$ volume of $20 \%$ lead acetate solution or $20 \%$ basic lead acetate solution has been added, the precipitation rate proves respectively $26 \sim 36.4 \%$ or $15.4 \sim 31.4 \%$; in case $1 / 20$ volume has been added only the rate $1 / 3.5$ of the former would be seen. The rate of discovery of precipitated indican nearly corresponds to $83 \sim 94 \%$ of the entire quantity.

(8) Extinction curve for the dehydrated chloroform-extract, no matter what kind of test urin, technic, oxydizing agent or precipitator may be emplyed, would come so near the typical curve for Thymolindogenide, yet not so perfectly; the quantitative value due to Principle No.(1) indicating certain indefinite increase, compared to that of Principle No. (2), the cause of which rests with the fact that when the Thymol and Indoxyl in urin condense themselves, though taking care not to formulate the indigo, there will be given birth to certain brown pigment soluble to chloroform, besides the Thymolindogenide.

(9) When the Thymolindogenide in the urine containing the trichloroacetic acid (urin T. ) is estimated, frequent washing of chloroform-extract may be necessary. Or else, the quantitative value indicates an abnormally high value, because of an increase in color tone caused by dehydrated chloroform-extract that has resulted from the increase of urinal trichloroacetic acid; so that one would have a marvelously high value at $80 \%$ density.

(10) The main motive for an increase in estimative value in urine $T$. is ascribed to those violet or reddish-violet tone that appear within reddishbrown dehydrated chloroform-extract. Its real state might be deemed, not only to depend upon the color reaction effected by Thymolindogenide against hydrochloric acid as well as trichloroacetic acid, but also due to certain color reaction shown by Thymolindogenide owing to a new appearance of certain ether-like aromatic substance.

(11) The estimation for urine containing the acetic acid (urine A.) proved that the highest value was reached when urinal acetic acid had indicated about $0.5 \%$ density; too much acetic acid found in the urine is apt to make difficult the extraction of the Thymolindogenide due to Chloroform, and leads to lower its 
value.

(12) The estimated value for urine T. has proved maximum at about $10 \%$ density of urinal trichloroacetic acid; the overmuch amount of urinal trichloroacetic acid, aided by a strengthened color tone maitained by chloroform-extract, rather serves to enhance the estimation.

(13) The highest value indicated by Thymolindogenide in one and same urine, shows slight difference between urine $A$ and urine $T$, in the light of principle No. (2); however, as to Principle No. (1); the latter undergoes about 1.5 times increase that of the former. Also, the value for Principle No.(1) against the highest value proved by Principle No. (2), amounts to in average 1.3 times in case of the former, but 2.5 times (in average) in the latter.

(14) The estimation value in urine $T$. should be corrected owing to a degree of increase. However, that degree tends to become unsteady due to estimating method, principle for the same, density of trichloroacetic acid or washing-method of chloroformextract and so on; so reliability could not be expected.

(15) The secondary extracted amount of Thymolindogenide for the 1st one which indicated greatest amount has proved, about $20 \%$ in case of urine A, $10 \%$ in urine T.; the extraction of Thymolindogenide proving better in latter case.'

(16) The estimation mistake shown in Principle No. (1) due to stufenphotometry and colorimetry indicates as about $5 \%$ (urine $\mathrm{A}$ ) and about $10 \%$ (urine T) increase in the latter.

4) From the above results as to the causes for misestimation of indican quantity, as well as about normal indican value, it was vindicated that there exists certain strong factors to lower the value in various estimation method for indican where Jolles's reaction deemed as it principle, as well as in such old-fashioned method in which precipitators are used; at the same time, the necessity for re-examination for those various achievement as to clinical significances of urinal indican thus clarified hitherto, by using new method, has become urgent. 